\title{
Sorbicillinoids from Fungi and Their Bioactivities
}

\author{
Jiajia Meng, Xiaohan Wang, Dan Xu, Xiaoxiang Fu, Xuping Zhang, Daowan Lai, Ligang Zhou * \\ and Guozhen Zhang *
}

Key Laboratory of Plant Pathology, Ministry of Agriculture/Department of Plant Pathology,

College of Plant Protection, China Agricultural University, Beijing 100193, China; mengjiajiax@163.com (J.M.);

wangxiaohan99@126.com (X.W.); cauxudan@163.com (D.X.); xiaoxiaofu@cau.edu.cn (X.F.);

zhangxuping5@163.com (X.Z.); dwlai@cau.edu.cn (D.L.)

* Correspondence: lgzhou@cau.edu.cn (L.Z.); zhanggzh@cau.edu.cn (G.Z.);

Tel.: +86-10-6273-1199 (L.Z.); +86-10-6273-3259 (G.Z.)

Academic Editor: Kira J. Weissman

Received: 6 April 2016; Accepted: 27 May 2016; Published: 1 June 2016

\begin{abstract}
Sorbicillinoids are important hexaketide metabolites derived from fungi. They have a variety of biological activities including cytotoxic, antioxidant, antiviral and antimicrobial activity. The unique structural features of the sorbicillinoids make them attractive candidates for developing new pharmaceutical and agrochemical agents. About 90 sorbicillinoids have been reported in the past few decades. This mini-review aims to briefly summarize their occurrence, structures, and biological activities.
\end{abstract}

Keywords: sorbicillin; sorbicillinoids; bisorbicillinoids; trisorbicillinoids; vertinoids; fungi; occurrence; biological activities

\section{Introduction}

Sorbicillinoids (also called vertinoids) belong to hexaketide metabolites in which the cyclization has taken place on the carboxylate terminus [1]. They have highly diverse bioactivities and have been isolated from either marine [2-4] or terrestrial fungi [5-7]. Many of them possess elaborate bicyclic or tricyclic systems that appear to arise from the oxidative dearomatizaton and subsequent dimerization/trimerization of sorbicillin (5). The presence of the $C 1^{\prime}-C 6^{\prime}$ sorbyl sidechain is another structural feature of these compounds. The term "sorbicillinoid" has come to encompass the family as a whole and generally refers to any compound that contains the carbon skeleton of sorbicillin.

Since first reported in 1948 by Cram et al., sorbicillinoids have been extensively studied [8,9]. In 2011, Harned and Volp reviewed the structures of 62 sorbicillinoids [1]. Since then, many new members of this family were isolated and great progress has been made [4,10-13]. According to the structural features, sorbicillinoids can be divided into four groups: monomeric sorbicillinoids, bisorbicillinoids, trisorbicillinoids, and hybrid sorbicillinoids. Biosynthesis and chemical synthesis have been extensively studied and reviewed $[1,11,14-17]$. In this mini-review, we focus on the occurrence and biological activities of sorbicillinoids, and 28 additional sorbicillinoids were added on the basis of the previous review [1].

\section{Occurrence}

Sorbicillinoids have a diverse distribution in fungi (Tables 1-4). Accordingly, their structures are shown in Figures 1-4. In total, about 90 sorbicillinoids have been isolated, and they were found mainly in terrestrial fungi, which contained nine genera, namely Acremonium, Aspergillus, Clonostachys, Emericella, Penicillium, Phaeoacremonium, Scytalidium, Trichoderma, and Verticillium, and partly in marine fungi that included five genera (i.e., Paecilomyces, Penicillium, Phialocephala, Trichoderma and Trichothecium). All these fungi belong to ascomycetes. 


\subsection{Monomeric Sorbicillinoids}

To date, 30 monomeric sorbicillinoids (Table 1 and Figure 1) have been isolated from Clonostachys, Emericella, Penicillium, Phaeoacremonium, Phialocephala, Scytalidium, Trichoderma, Trichothecium and Verticillium species.

Sorbicillinol (1) was found to be highly reactive and it was the biosynthetic precursor of the other sorbicillinoid family members [11].

Sorrentanone (=3-hydroxy-2,5-dimethyl-6-(1'-oxo-2' ,4'-dienylhexyl)-1,4-benzoquinone, 26) was the benzoquinone structure of sohirnone $B(8)$, meaning that it was imagined arising from the oxidation of sohirnone B (8) [5,18]. Similarly, 2-(2',3'-dihydrosorbyl)-3,6-dimethyl-5-hydroxy-1,4-benzoquinone (25) was the benzoquinone of sohirnone C (15) $[5,19]$.

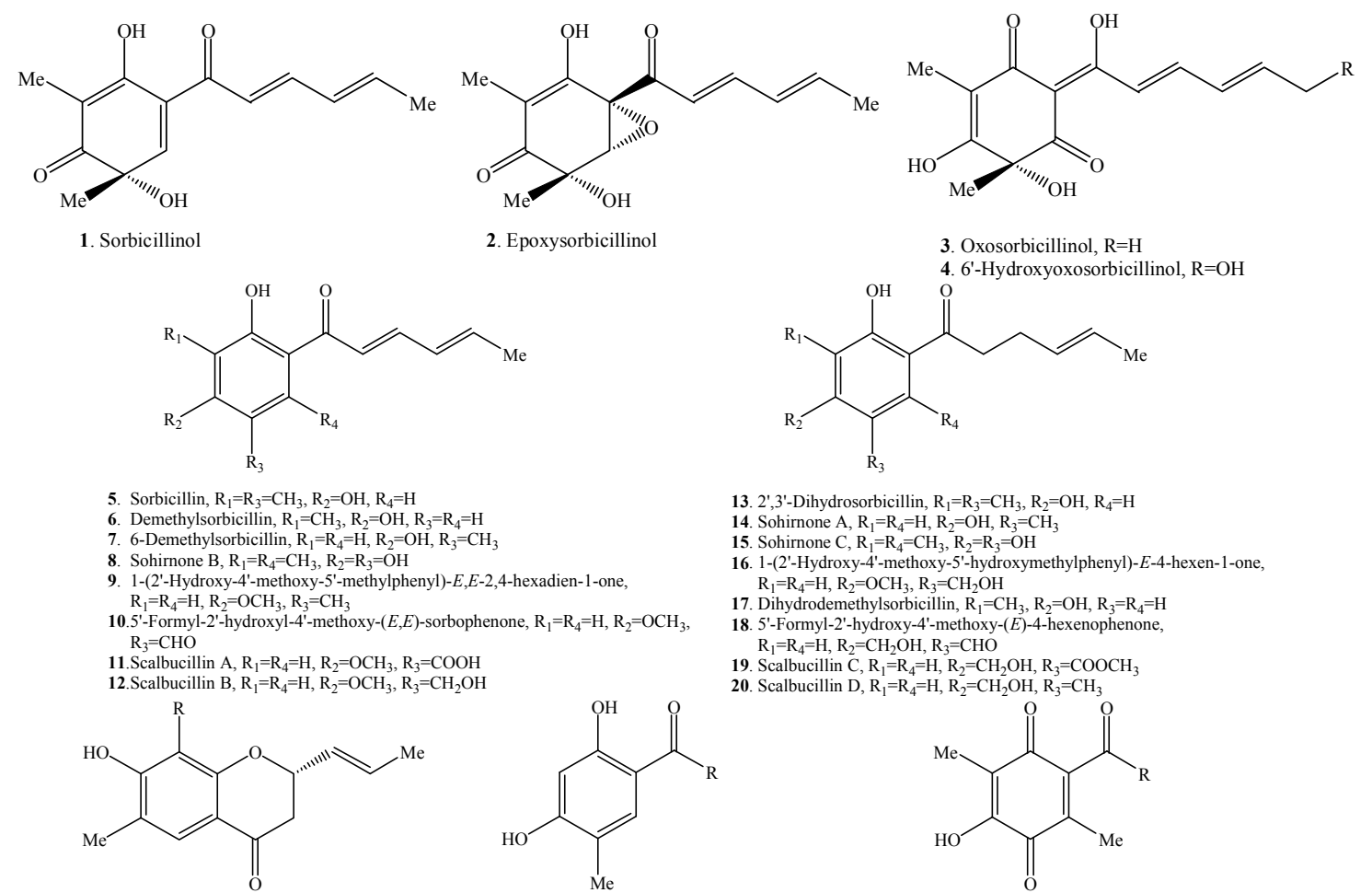<smiles>C/C=C\C=C\C(=O)c1cc(C)c(O)c(C)c1O</smiles>

23. (E)-6-(2,4-Dihydroxyl-5-methylphenyl)-6oxo-2-hexenoic acid, $\mathrm{R}=\mathrm{COOH}_{\mathrm{C}}$

24. 6-(2,4-Dihydroxyl-5-methylphenyl)25. 2-(2',3'-Dihydrosorbyl)-3,6-dimethyl-5-hydroxy-1,46-oxohexanoic acid, $\mathrm{R}=>\mathrm{COOH}$ benzoquinone, $\mathrm{R}=>\mathrm{Me}$ 26. Sorrentanone, $\mathrm{R}=$
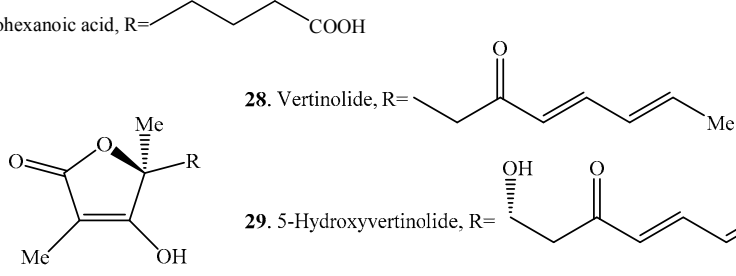

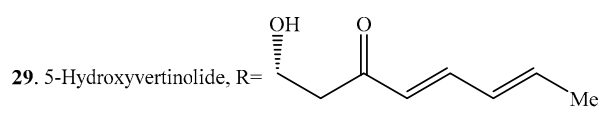<smiles>CC=CC=CC(=O)CC[OH+]</smiles>

Figure 1. Structures of the monomeric sorbicillinoids (1-30) isolated from fungi. 
Table 1. Occurrence of the monomeric sorbicillinoids (1-30) in fungi.

\begin{tabular}{|c|c|c|}
\hline Sorbicillinoid & Fungus and its Origin & Ref. \\
\hline Sorbicillinol (1) & Trichoderma sp. USF-2690 from a soil sample & [14] \\
\hline Epoxysorbicillinol (2) & Trichoderma longibrachiatum from the sponge Haliclona sp. & [20] \\
\hline Oxosorbicillinol (3) & $\begin{array}{l}\text { Penicillium chrysogenum E01-10/3 from the sponge Ircinia fasciculata } \\
\text { Penicillium notatum from a benchtop contamination } \\
\text { Penicillium sp. 06T121 from a soil sample } \\
\text { Trichoderma sp. USF-2690 from a soil sample }\end{array}$ & $\begin{array}{l}{[21]} \\
{[5]} \\
{[22]} \\
{[23]}\end{array}$ \\
\hline 6'-Hydroxyoxosorbicillinol (4) & Penicillium sp. $06 \mathrm{~T} 121$ from a soil sample & [22] \\
\hline Sorbicillin (5) & $\begin{array}{c}\text { Clonostachys rosea YRS-06 from a soil sample } \\
\text { Emericella sp. IFM57991 and its origin was not clear } \\
\text { Penicillium chrysogenum Q176 and its origin was not clear } \\
\text { Penicillium chrysogenum E01-10/3 from the sponge Ircinia fasciculata } \\
\text { Penicillium notatum and its origin was not clear } \\
\text { Penicillium sp. P-1 as an endophyte from the stems of Huperzia serrata } \\
\text { Trichoderma longibrachiatum UAMH } 4159 \text { and its origin was not clear } \\
\text { Trichoderma sp. from the seastar Acanthaster planci } \\
\text { Trichoderma sp. f-13 from a marine sediment } \\
\text { Trichoderma sp. PR-35 as an endophyte from Paeonia delavayi } \\
\text { Trichoderma sp. USF-2690 from a soil sample } \\
\text { Trichothecium sp. from a marine sediment } \\
\text { Verticillium intertextum and its origin was not clear }\end{array}$ & $\begin{array}{c}{[13]} \\
{[24]} \\
{[25]} \\
{[1,21]} \\
{[8,9]} \\
{[7]} \\
{[26]} \\
{[4]} \\
{[27]} \\
{[28]} \\
{[29]} \\
{[30]} \\
{[31,32]}\end{array}$ \\
\hline Demethylsorbicillin (6) & Trichoderma sp. USF-2690 from a soil sample & [23] \\
\hline 6-Demethylsorbicillin (7) & Trichoderma sp. f-13 from a marine sediment & [27] \\
\hline Sohirnone B (8) & Penicillium notatum from a benchtop contamination & [5] \\
\hline 1-(2'-Hydroxy-4'-methoxy-5'-methylphenyl)-E,E-2,4-hexadien-1-one (9) & $\begin{array}{l}\text { Phaeoacremonium sp. NRRL32148 from the surface of stromata of Hypoxylon truncatum } \\
\text { formed on a dead hardwood branch } \\
\text { Scytalidium album MSX51631 from a soil sample }\end{array}$ & $\begin{array}{l}{[33]} \\
{[12]}\end{array}$ \\
\hline 5'-Formyl-2'-hydroxyl-4'-methoxy-(E,E)-sorbophenone (10) & $\begin{array}{l}\text { Phaeoacremonium sp. NRRL32148 from the surface of stromata of Hypoxylon truncatum } \\
\text { formed on a dead hardwood branch } \\
\text { Scytalidium album MSX51631 from a soil sample } \\
\text { Scytalidium sp. FY as an immunizing commensal of Douglasfir utility poles }\end{array}$ & $\begin{array}{l}{[33]} \\
{[12]} \\
{[34]}\end{array}$ \\
\hline Scalbucillin A (11) & Scytalidium album MSX51631 from a soil sample & [12] \\
\hline Scalbucillin B (12) & Scytalidium album MSX51631 from a soil sample & [12] \\
\hline
\end{tabular}


Table 1. Cont.

\begin{tabular}{|c|c|c|}
\hline Sorbicillinoid & Fungus and its Origin & Ref. \\
\hline $2^{\prime}, 3^{\prime}$-Dihydrosorbicillin (13) & $\begin{array}{l}\text { Penicillium chrysogenum R03-8/4 from the sponge Tethya aurantium } \\
\text { Penicillium chrysogenum } \text { E01-10/3 from the sponge Ircinia fasciculata } \\
\text { Penicillium notatum from a benchtop contamination } \\
\text { Penicillium sp. P-1 as an endophyte from the stems of Huperzia serrata } \\
\text { Trichoderma sp. from the seastar Acanthaster planci } \\
\text { Trichoderma sp. f-13 from a marine sediment } \\
\text { Verticillium intertextum from a laboratory contaminant }\end{array}$ & $\begin{array}{c}{[35]} \\
{[11]} \\
{[5]} \\
{[7]} \\
{[4]} \\
{[27]} \\
{[31,32]}\end{array}$ \\
\hline Sohirnone A (14) & $\begin{array}{l}\text { Penicillium notatum from a benchtop contamination } \\
\text { Trichoderma sp. f- } 13 \text { from a marine sediment }\end{array}$ & {$[5]$} \\
\hline Sohirnone C (15) & Penicillium notatum from a benchtop contamination & [5] \\
\hline 1-(2'-Hydroxy-4'-methoxy-5'-hydroxymethylphenyl)-E-4-hexen-1-one (16) & $\begin{array}{l}\text { Phaeoacremonium sp. from the surface of stromata of Hypoxylon truncatum formed on a } \\
\text { dead hardwood branch } \\
\text { Scytalidium album MSX51631 from a soil sample }\end{array}$ & $\begin{array}{l}{[33]} \\
{[12]}\end{array}$ \\
\hline Dihydrodemethylsorbicillin (17) & Phialocephala sp. FL30r from a deep sea sediment & [36] \\
\hline 5'-Formyl-2'-hydroxy-4'-methoxy-(E)-4-hexenophenone (18) & $\begin{array}{c}\text { Scytalidium album MSX51631 from a soil sample } \\
\text { Scytalidium sp. FY as an immunizing commensal of Douglasfir utility poles }\end{array}$ & {$[12]$} \\
\hline Scalbucillin C (19) & Scytalidium album MSX51631 from a soil sample & [12] \\
\hline Scalbucillin D (20) & Scytalidium album MSX51631 from a soil sample & [12] \\
\hline (2S)-2,3-Dihydro-7-hydroxy-6,8-dimethyl-2-[(E)-prop-1-enyl]-chroman-4-one (21) & $\begin{array}{l}\text { Trichoderma sp. from the seastar Acanthaster planci } \\
\text { Penicillium sp. P-1 as an endophyte from the stems of Huperzia serrata }\end{array}$ & $\begin{array}{l}{[4]} \\
{[7]}\end{array}$ \\
\hline (2S)-2,3-Dihydro-7-hydroxy-6-methyl-2- [(E)-prop-1-enyl]-chroman-4-one (22) & Trichoderma sp. from the seastar Acanthaster planci & [4] \\
\hline (E)-6-(2,4-Dihydroxyl-5-methylphenyl)-6-oxo-2-hexenoic acid (23) & Trichoderma sp. JH8 from the soil of saline lands & [6] \\
\hline 6-(2,4-Dihydroxyl-5-methylphenyl)-6-oxohexanoic acid (24) & Trichoderma sp. JH8 from the soil of saline lands & [6] \\
\hline 2-(2',3' -Dihydrosorbyl)-3,6-dimethyl-5-hydroxy-1,4-benzoquinone (25) & Penicillium terrestre from a marine sediment & [19] \\
\hline Sorrentanone = 3-hydroxy-2,5-dimethyl-6-(1'-oxo-2', $4^{\prime}$-dienylhexyl)-1,4-benzoquione (26) & Penicillium chrysogenum SC13887 and its origin was not clear & [18] \\
\hline (4'Z)-Sorbicillin (27) & Trichoderma sp. from the seastar Acanthaster planci & [4] \\
\hline Vertinolide (28) & $\begin{array}{l}\text { Trichoderma viride from the sponge Agelas dispar } \\
\text { Trichoderma sp. from the sponge Agelas dispar } \\
\text { Verticillium intertextum from a laboratory contaminant }\end{array}$ & $\begin{array}{c}{[3]} \\
{[37]} \\
{[31,38]}\end{array}$ \\
\hline 5-Hydroxyvertinolide (29) & Trichoderma longibrachiatum UAMH 4159 and its origin was not clear & [39] \\
\hline 5-Epihydroxyvertinolide (30) & Trichoderma sp. USF-2690 from a soil sample & [17] \\
\hline
\end{tabular}




\subsection{Bisorbicillinoids}

Bisorbicillinoids are also called dimeric sorbicillinoids, which consist of two sorbicillinoid monomers (Table 2), whose structures are shown in Figure 2. Up to now, 30 bisorbicillinoids have been isolated from fungi. These compounds are mainly distributed in the genera Acremonium, Aspergillus, Clonostachys, Penicillium, Phialocephala, Trichoderma, Trichothecium and Verticillium.

Table 2. Occurrence of the bisorbicillinoids (31-60) in fungi.

\begin{tabular}{|c|c|c|}
\hline Sorbicillinoid & Fungus and Its Origin & Ref. \\
\hline \multirow{5}{*}{ Bisvertinol (31) } & Aspergillus sp. FKI-1746 from a mangrove slurry sample & [40] \\
\hline & Trichoderma longibrachiatum UAMH 4159 and its origin was not clear & [26] \\
\hline & Trichoderma viride from the sponge Agelas dispar & [3] \\
\hline & Trichoderma sp. from the sponge Agelas dispar & [37] \\
\hline & Verticillium intertextum from a laboratory contaminant & [41] \\
\hline \multirow{2}{*}{ Dihydrobisvertinol (32) } & Aspergillus sp. FKI-1746 from a mangrove slurry sample & [40] \\
\hline & Verticillium intertextum from a laboratory contaminant & [41] \\
\hline \multirow{10}{*}{$\begin{array}{c}\text { Isodihydrobisvertinol (33) } \\
\text { Bisvertinolone (34) }\end{array}$} & Verticillium intertextum from a laboratory contaminant & [41] \\
\hline & Acremonium strictum and its origin was not clear & [42] \\
\hline & Penicillium chrysogenum E01-10/3 from the sponge Ircinia fasciculata & [21] \\
\hline & Penicillium citrinum SpI080624G1f01 from a marine sponge & [43] \\
\hline & Penicillium notatum from a benchtop contamination & [5] \\
\hline & Trichoderma longibrachiatum UAMH 4159 and its origin was not clear & [26] \\
\hline & Trichoderma sp. f-13 from a marine sediment & [27] \\
\hline & Trichoderma sp. JH8 from the soil of saline lands & [6] \\
\hline & Trichoderma sp. USF-2690 isolated from a soil sample & [44] \\
\hline & Verticillium intertextum from a laboratory contaminant & [41] \\
\hline 16,17-Dihydrobisvertinolone (35) & Penicillium terrestre from a marine sediment & [19] \\
\hline 10,11-Dihydrobisvertinolone (36) & Trichoderma sp. $\mathrm{f}-13$ from a marine sediment & [27] \\
\hline Tetrahydrobisvertinolone (37) & Penicillium terrestre from a marine sediment & [19] \\
\hline Isobisvertinol (38) & Aspergillus sp. FKI-1746 from a mangrove slurry sample & [40] \\
\hline Sorbicillamine D (39) & Penicillium sp. F23-2 from a deep-sea sediment & [10] \\
\hline Sorbicillamine B (40) & Penicillium sp. F23-2 from a deep-sea sediment & [10] \\
\hline Sorbicillamine C (41) & Penicillium sp. F23-2 from a deep-sea sediment & [10] \\
\hline \multirow{14}{*}{ Trichodimerol = MS-182123 (42) } & Clonostachys rosea YRS-06 from a soil sample & [13] \\
\hline & Penicillium chrysogenum V39673 and its origin was not clear & {$[45,46]$} \\
\hline & Penicillium citrinum SpI080624G1f01 from a marine sponge & [43] \\
\hline & Penicillium terrestre from a marine sediment & [47] \\
\hline & Trichoderma citrinoviride ITEM 4484 from the soil under the tree Abies sp. & [48] \\
\hline & Trichoderma viride from the sponge Agelas dispar & [3] \\
\hline & Trichoderma longibrachiatum UAMH 4159 and its origin was not clear & [26] \\
\hline & Trichoderma sp. from the straws of rice & [49] \\
\hline & Trichoderma sp. from the sponge Agelas dispar & [37] \\
\hline & Trichoderma sp. $\mathrm{f}-13$ from a marine sediment & [27] \\
\hline & Trichoderma sp. JH8 from the soil of saline lands & [6] \\
\hline & Trichoderma sp. USF-2690 from a soil sample & [44] \\
\hline & Trichothecium sp. from a marine sediment & [30] \\
\hline & Unidentified fungus B00853 from a soil sample & [50] \\
\hline Demethyltrichodimerol (43) & Trichoderma sp. USF-2690 isolated from a soil sample & [44] \\
\hline \multirow{5}{*}{ Dihydrotrichodimerol (44) } & Clonostachys rosea YRS-06 from a soil sample & [13] \\
\hline & Penicillium terrestre from a marine sediment & [47] \\
\hline & Trichoderma citrinoviride ITEM 4484 from the soil under the tree Abies sp. & {$[48,51]$} \\
\hline & Trichoderma sp. f- 13 from a marine sediment & [27] \\
\hline & Unidentified fungus B00853 from a soil sample & [50] \\
\hline \multirow{2}{*}{ Tetrahydrotrichodimerol (45) } & Clonostachys rosea YRS-06 from a soil sample & [13] \\
\hline & Penicillium terrestre from a marine sediment & [47] \\
\hline Bisorbibetanone (46) & Trichoderma sp. USF-2690 isolated from a soil sample & [52] \\
\hline \multirow{3}{*}{ Bisvertinoquinol (47) } & Penicillium notatum from a benchtop contamination & [5] \\
\hline & Trichoderma sp. f-13 from a marine sediment & [27] \\
\hline & Verticillium intertextum from a laboratory contaminat & {$[31,32]$} \\
\hline \multirow{3}{*}{ Bisorbicillinol (48) } & Penicillium notatum from a benchtop contamination & [5] \\
\hline & Trichoderma sp. f-13 from a marine sediment & [27] \\
\hline & Trichoderma sp. USF-2690 from a soil sample & [44] \\
\hline
\end{tabular}


Table 2. Cont.

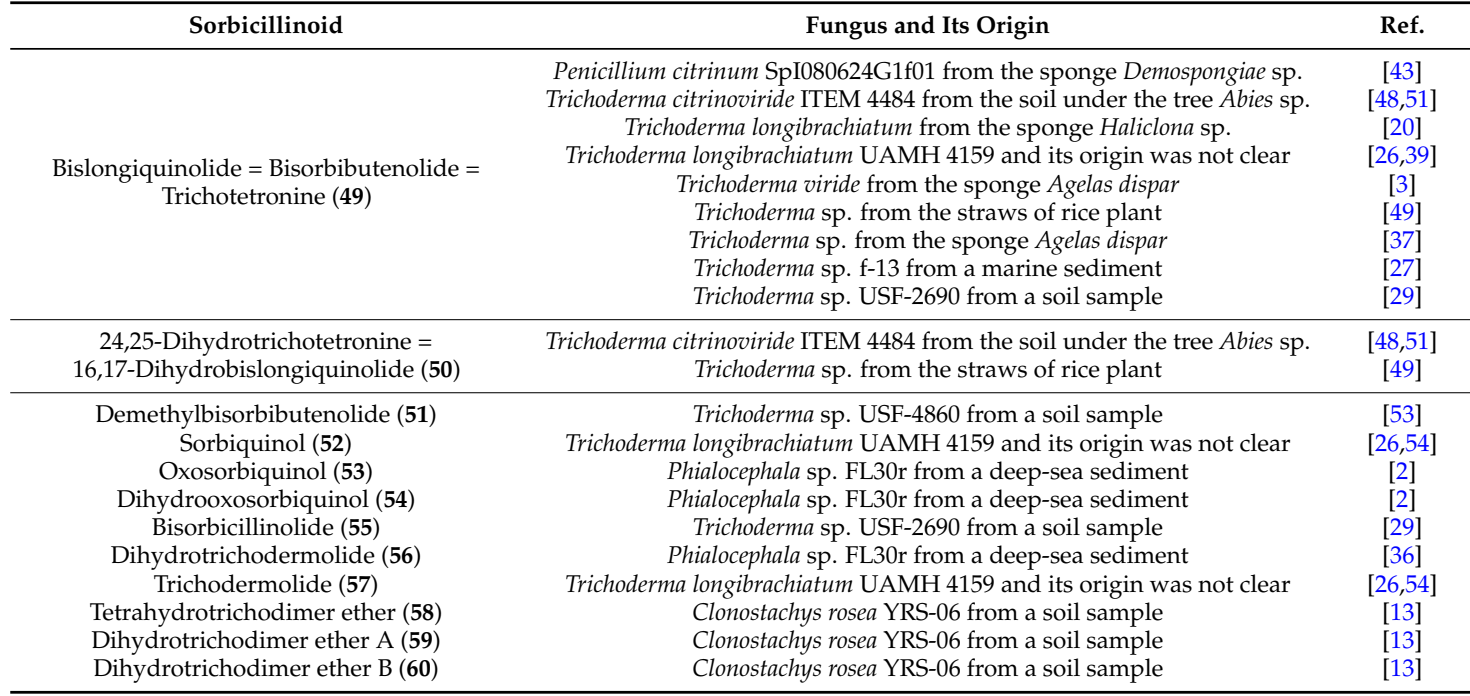

Note: Compounds 36, 39-41 and 56-60 were not included in the last review [1].

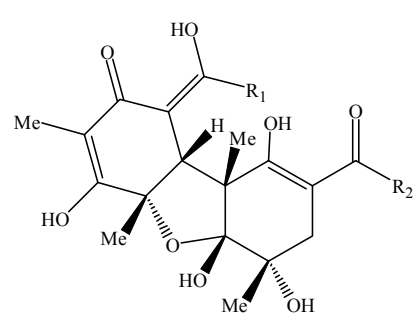

31. Bisvertinol, $\mathrm{R}_{1}=$

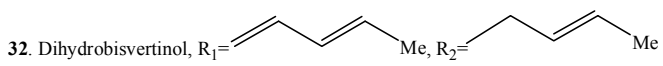

33. Isodihydrobisvertinol, $\mathrm{R}_{1}=$

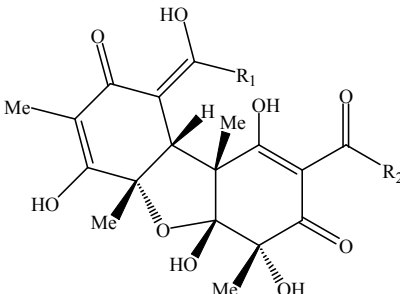

34. Bisvertinolone, $\mathrm{R}_{1}=$

35. 16,17-Dihydrobisvertinolone, $\mathrm{R}_{1}=$

36. 10,11-Dihydrobisvertinolone, $\mathrm{R}_{1}=$

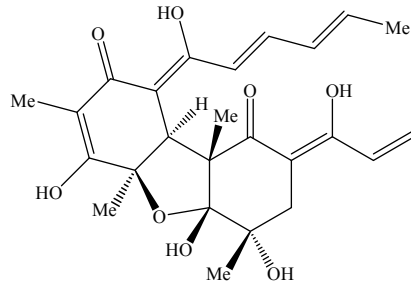

38. Isobisvertinol

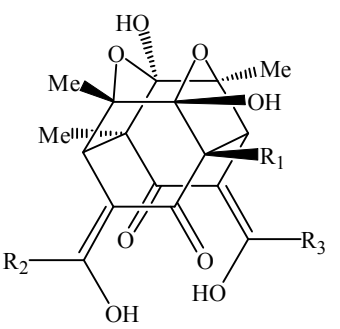

$\mathrm{Me}$

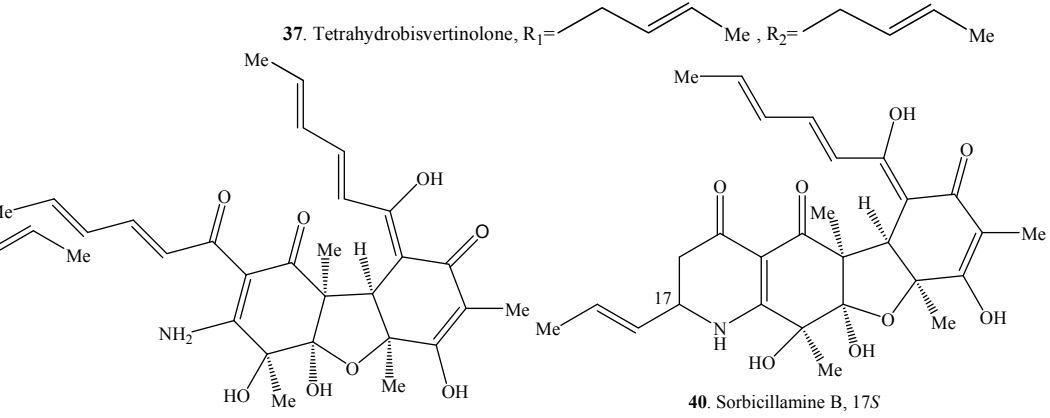

39. Sorbicillamine D
40. Sorbicillamine B, $17 \mathrm{~S}$

41. Sorbicillamine $\mathrm{C}, 17 R$

42. Trichodimerol, $\mathrm{R}_{1}=\mathrm{CH}_{3}, \mathrm{R}_{2}=$

43. Demethyltrichodimerol, $\mathrm{R}_{1}=\mathrm{H}, \mathrm{R}_{2}=$

44. Dihydrotrichodimerol, $\mathrm{R}_{1}=\mathrm{CH}_{3}, \mathrm{R}_{2}=$

45. Tetrahydrotrichodimerol, $\mathrm{R}_{1}=\mathrm{CH}_{3}, \mathrm{R}_{2}=$

Figure 2. Cont. 


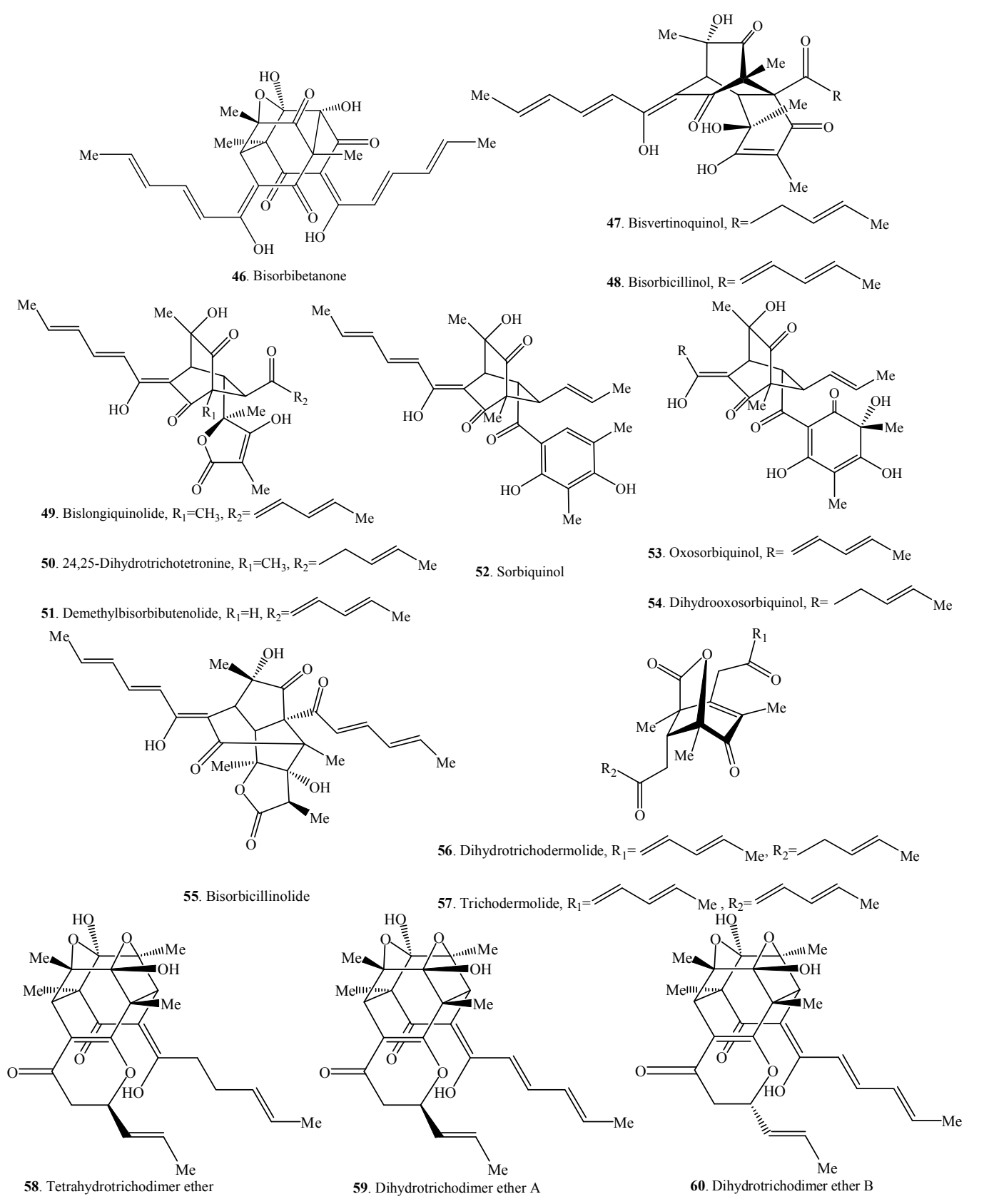

Figure 2. Structures of the bisorbicillinoids (31-60) isolated from fungi.

\subsection{Trisorbicillinoids}

Trisorbicillinoids are also called trimeric sorbicillinoids. Up to date, only five trimeric sorbicillinoids have been isolated from marine fungi (i.e., Penicillium sp. F23-2 and Phialocephala sp. FL30r) (Table 3 and Figure 3). Among them, sorbicillamine E (65) was a compound containing N element [10]. 
Table 3. Occurrence of the trimeric sorbicillinoids (61-65) in fungi.

\begin{tabular}{clc}
\hline Sorbicillinoid & Fungus and Its Origin & Ref. \\
\hline Trisorbicillinone A (61) & Phialocephala sp. FL30r from a deep-sea sediment & {$[55]$} \\
Trisorbicillinone B (62) & Phialocephala sp. FL31r from a deep-sea sediment & {$[56]$} \\
Trisorbicillinone C (63) & Phialocephala sp. FL32r from a deep-sea sediment & {$[56]$} \\
Trisorbicillinone D (64) & Phialocephala sp. FL33r from a deep-sea sediment & {$[56]$} \\
Sorbicillamine E (65) & Penicillium sp. F23-2 from a deep-sea sediment & {$[10]$} \\
\hline
\end{tabular}

Note: Compound 65 was not included in the last review [1].
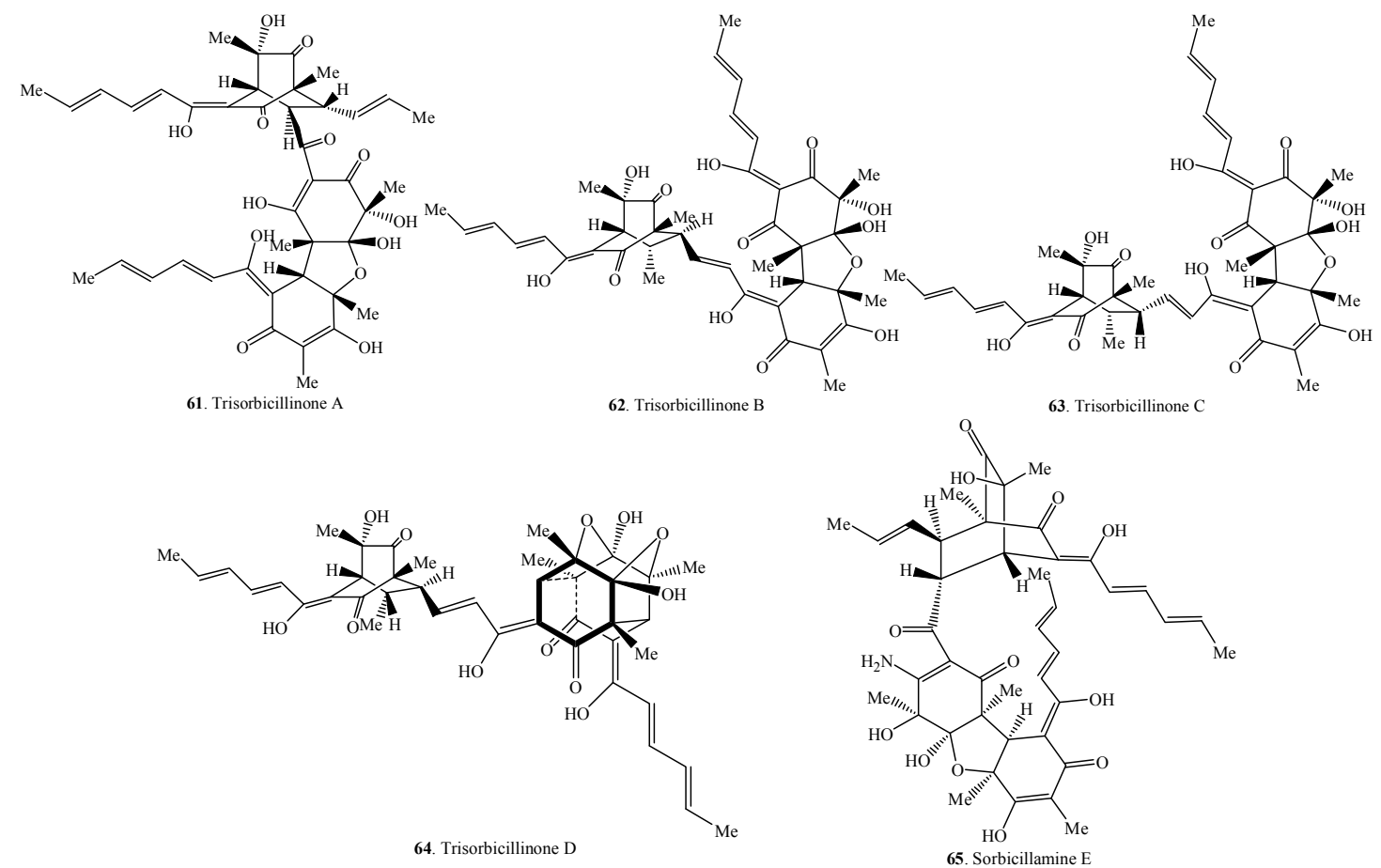

Figure 3. Structures of the trimeric sorbicillinoids (61-65) isolated from fungi.

\subsection{Hybrid Sorbicillinoids}

Hybrid sorbicillinoids are proposed to be derived from either a Diels-Alder or a Michael reaction of a monomeric sorbicillinoid diene and a second non-sorbicillinoid dienophile. About 25 hybrid sorbicillinoids have been isolated from fungi so far.

The structure of sorbicillamine A (78) was a tentative assignment for the C-2/C-7 unit, which might exist as either enol or keto tautomers, and they were interconverting on the NMR timescale in solution [10].

Compound 73 from an intertidal marine fungus Paecilomyces marquandii was an unnamed sorbicillinoid urea [57]. Chloctanspirones A (74) and B (75) containing chlorine were isolated from Penicillium terrestre derived from a marine sediment. The differences between them were their absolute configuration at C-19 [58]. Similarly, both sorbicatechols A (76) and B (77) were isolated from the marine sediment-derived fungus Penicillium chrysogenum PJX-17, and their differences were the absolute configuration at C-7 [59].

Unnamed urea (73), sorbicillamine A (78), sorbicillactone A (85), and sorbicillactone B (86) were a class of $\mathrm{N}$-containing compounds $[10,21,57]$. Interestingly, the $\mathrm{N}$-containing sorbicillinoids including dimeric sorbicillamines D (39), B (40), C (41), and trimeric sorbicillamine E (65) were all isolated from marine fungi (Tables 2-4). Except urea 73 from the genus Paecilomyces, others were isolated from the genus Penicillium. 
Table 4. Occurrence of the hybrid sorbicillinoids (66-90) in fungi.

\begin{tabular}{|c|c|c|}
\hline Sorbicillinoid & Fungus and Its Origin & Ref. \\
\hline Rezishanone A (66) & Penicillium notatum from a benchtop contamination & [5] \\
\hline Rezishanone B (67) & Penicillium notatum from a benchtop contamination & [5] \\
\hline \multirow{5}{*}{ Rezishanone $\mathrm{C}=$ Sorbivinetone $(\mathbf{6 8})$} & Penicillium chrysogenum isolated from the sponge Ircinia fasciculata & {$[21]$} \\
\hline & Penicillium notatum from a benchtop contamination & [5] \\
\hline & Trichoderma viride from the sponge Agelas dispar & {$[3]$} \\
\hline & Trichoderma sp. isolated from the sponge Agelas dispar & [37] \\
\hline & Unidentified fungus B00853 from a soil sample & [50] \\
\hline \multirow{2}{*}{ Rezishanone D (69) } & Penicillium notatum from a benchtop contamination & [5] \\
\hline & Unidentified fungus B00853 collected from a soil sample & [50] \\
\hline Spirosorbicillinol A (70) & Trichoderma sp. USF-4860 from a soil sample & {$[60]$} \\
\hline Spirosorbicillinol B (71) & Trichoderma sp. USF-4860 from a soil sample & [60] \\
\hline Spirosorbicillinol C (72) & Trichoderma sp. USF-4860 from a soil sample & [60] \\
\hline Unnamed sorbicillinoid urea (73) & Paecilomyces marquandii BAFC 486 from a marine sediment & [57] \\
\hline Chloctanspirone A (74) & Penicillium terrestre from a marine sediment & [58] \\
\hline Chloctanspirone B (75) & Penicillium terrestre from a marine sediment & [58] \\
\hline Sorbicatechol A (76) & Penicillium chrysogenum PJX-17 from a marine sediment & [59] \\
\hline Sorbicatechol B (77) & Penicillium chrysogenum PJX-17 from a marine sediment & [59] \\
\hline Sorbicillamine A (78) & Penicillium sp. F23-2 from a deep-sea sediment & [10] \\
\hline Sorbiterrin A (79) & Penicillium terrestre from a marine sediment & [61] \\
\hline JBIR-59 (80) & Penicillium citrinum SpI080624G1f01 from the sponge Demospongiae sp. & {$[43]$} \\
\hline JBIR-124 (81) & Penicillium citrinum SpI080624G1f01 from the sponge Demospongiae sp. & {$[62]$} \\
\hline Sorbifuranone A (82) & Penicillium chrysogenum E03-8/4 from the sponge Tethya aurantium & [35] \\
\hline Sorbifuranone B (83) & Penicillium chrysogenum E03-8/4 from the sponge Tethya aurantium & [35] \\
\hline Sorbifuranone C (84) & Penicillium chrysogenum E03-8/4 from the sponge Tethya aurantium & [35] \\
\hline \multirow{2}{*}{ Sorbicillactone A (85) } & Penicillium chrysogenum E01-10/3 from the sponge Ircinia fasciculata & [21] \\
\hline & Penicillium chrysogenum R03-8/4 from the sponge Tethya aurantium & [35] \\
\hline Sorbicillactone B (86) & Penicillium chrysogenum E01-10/3 from the sponge Ircinia fasciculata & [21] \\
\hline \multirow{2}{*}{ Trichodermanone A (87) } & Trichoderma viride from the sponge Agelas dispar & [3] \\
\hline & Trichoderma sp. from the sponge Agelas dispar & [37] \\
\hline \multirow{2}{*}{ Trichodermanone B (88) } & Trichoderma viride from the sponge Agelas dispar & {$[3]$} \\
\hline & Trichoderma sp. from the sponge Agelas dispar & [37] \\
\hline \multirow{2}{*}{ Trichodermanone C (89) } & Trichoderma viride from the sponge Agelas dispar & {$[3]$} \\
\hline & Trichoderma sp. from the sponge Agelas dispar & [37] \\
\hline \multirow[b]{2}{*}{ Trichodermanone D (90) } & Trichoderma viride from the sponge Agelas dispar & {$[3]$} \\
\hline & Trichoderma sp. from the sponge Agelas dispar & [37] \\
\hline
\end{tabular}

Note: Compounds 74-79 were not included in the last review [1].

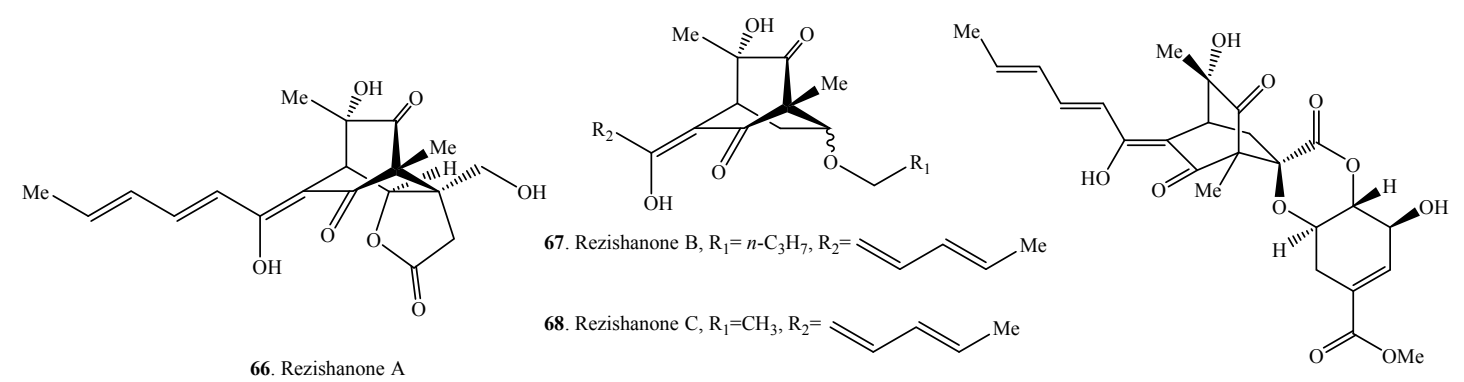

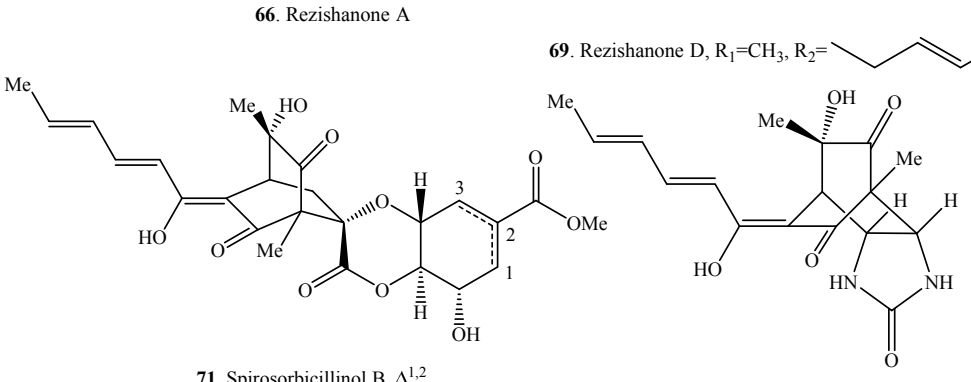

71. Spirosorbicillinol B, $\Delta^{1,2}$

72. Spirosorbicillinol $\mathrm{C}, \Delta^{2,3}$
73. Unnamed sorbicillinoid urea

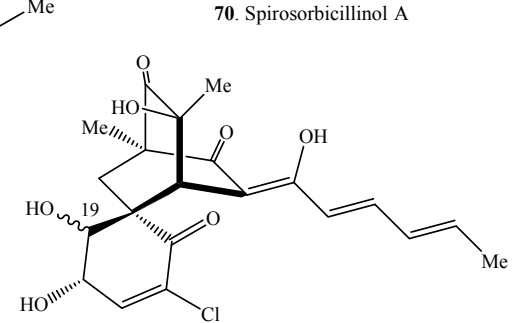

74. Chloctanspirone $\mathrm{A}, 19 R$

75. Chloctanspirone B, $19 S$

Figure 4. Cont. 

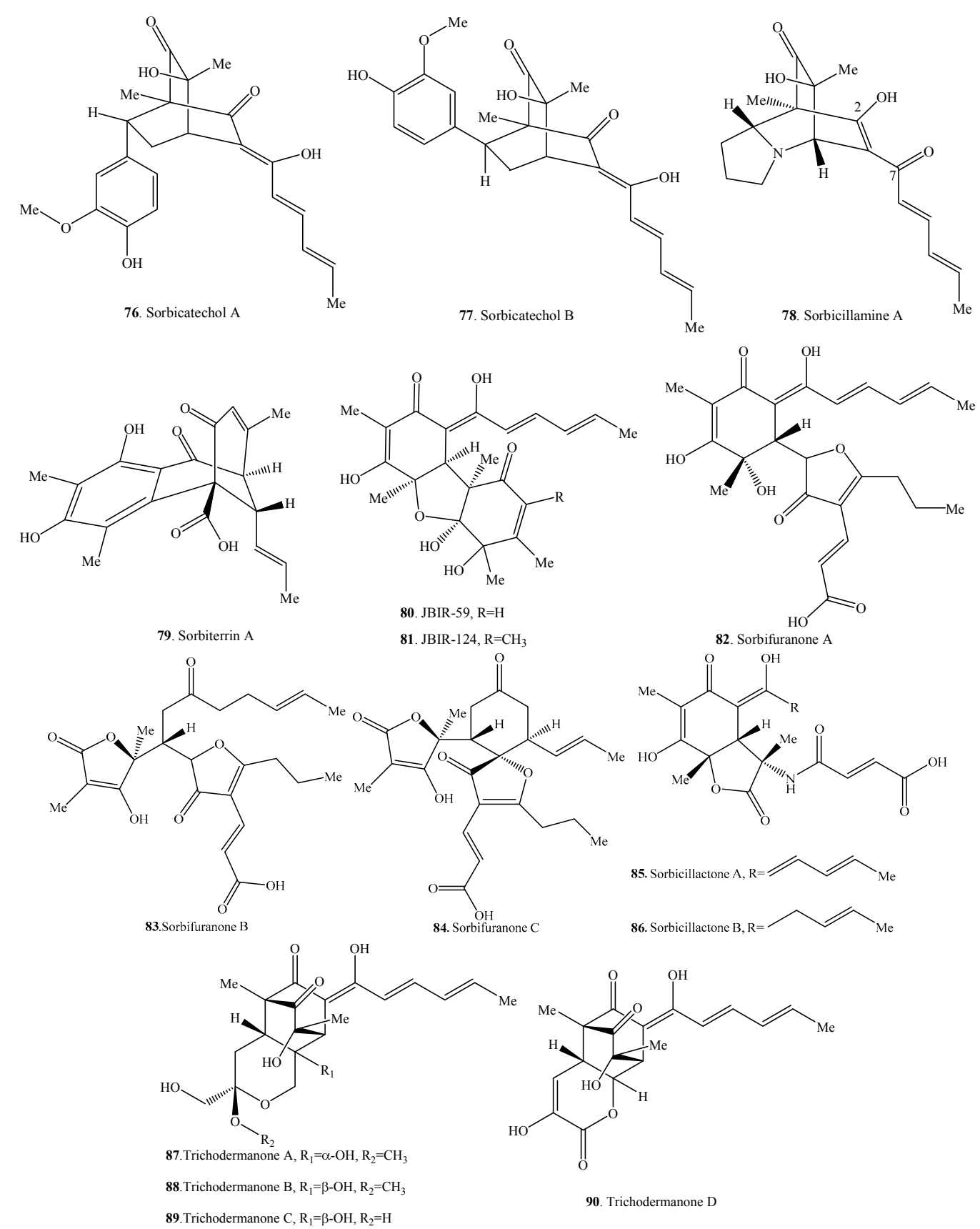

90. Trichodermanone D

Figure 4. Structures of the hybrid sorbicillinoids (66-90) isolated from fungi.

\section{Biological Activities}

\subsection{Cytotoxic Activity}

Many sorbicillinoids were screened to have cytotoxic activities, which are summarized in Table 5. (2S)-2,3-Dihydro-7-hydroxy-6,8-dimethyl-2-[(E)-prop-1-enyl]-chroman-4-one (21) and (2S)-2,3-dihydro-7-hydroxy-6-methyl-2-[(E)-prop-1-enyl]-chroman-4-one (22) displayed significant activities against the human breast cancer cell line MCF-7 with $\mathrm{IC}_{50}$ values of 9.51 and $7.82 \mu \mathrm{g} / \mathrm{mL}$, respectively, and $2^{\prime}, 3^{\prime}$-dihydrosorbicillin (13) showed moderate cytotoxicity against various human cancer cell lines (colon cancer cell line Lovo, hepatic cancer cell line Bel-7402, lung cancer line A549, nasopharyngeal carcinoma cell lines CNE1, CNE2, KB and SUNE1) with $\mathrm{IC}_{50}$ values ranging from 9.19 to $21.93 \mu \mathrm{g} / \mathrm{mL}$ [4]. 
Table 5. Cytotoxic activity of the screened sorbicillinoids from fungi.

\begin{tabular}{|c|c|c|}
\hline Sorbicillinoid & Cytotoxic Activity & Ref. \\
\hline Sorbicllin (5) & $\begin{array}{c}\mathrm{IC}_{50} \text { of } 12.7 \mu \mathrm{M} \text { on HL-60 (Leukemia) cell line. } \\
\text { IC }_{50} \text { s of } 1.6 \text { and } 27.2 \mu \mathrm{M} \text { on HeLa and HepG2 cells, respectively. } \\
\text { IC }_{50} \text { of } 6.55 \text { to } 28.55 \mu \mathrm{M} \text { on HL-60, U937 and T47D cell lines. }\end{array}$ & $\begin{array}{c}{[27]} \\
{[7]} \\
{[30]}\end{array}$ \\
\hline 6-Demethylsorbicillin (7) & $\mathrm{IC}_{50}$ of $23.9 \mu \mathrm{M}$ on HL-60 cell line. & [27] \\
\hline 1-(2'-Hydroxy-4'-methoxy-5'-methylphenyl)-E,E-2,4-hexadien-1-one (9) & $\mathrm{IC}_{50} \mathrm{~S}$ of 65.2 and $15.1 \mu \mathrm{M}$ on MDA-MB-435 and SW-620 cell lines at $72 \mathrm{~h}$, respectively. & [12] \\
\hline 5'-Formyl-2' 'hydroxyl-4'-methoxy- $(E, E)$-sorbophenone (10) & $\begin{array}{l}\text { IC }_{50} \mathrm{~S} \text { of } 1.5 \text { and } 0.5 \mu \mathrm{M} \text { on MDA-MB-435 (melanoma) and SW- } 620 \text { (colon) cell lines at } 72 \mathrm{~h} \text {, respectively, } \\
\text { IC } 50 \text { of } 3.1 \mu \mathrm{M} \text { on OSU-CLL (lymphocytic leukemia) cell line at } 48 \mathrm{~h} \text {. }\end{array}$ & [12] \\
\hline Scalbucillin B (12) & $\mathrm{IC}_{50} \mathrm{~s}$ of 67.9 and $16.0 \mu \mathrm{M}$ on MDA-MB- 435 and SW- 620 cell lines at $72 \mathrm{~h}$, respectively. & [12] \\
\hline $2^{\prime}, 3^{\prime}$-Dihydrosorbicillin (13) & $\begin{array}{l}\text { IC }_{50} \text { s of } 7.4 \text { and } 44.4 \mu \mathrm{M} \text { on HeLa and HepG2 cells, respectively. } \\
\text { IC }_{50} \text { s of } 9.19 \text { to } 21.93 \mu \mathrm{g} / \mathrm{mL} \text { on various human cancer cell lines. }\end{array}$ & {$[7]$} \\
\hline Dihydrodemethylsorbicillin (17) & $\mathrm{IC}_{50} \mathrm{~s}$ of 0.1 and $4.8 \mu \mathrm{M}$ on P388 and K562 cell lines, respectively. & [36] \\
\hline 5'-Formyl-2'-hydroxy-4'-methoxy-(E)-4-hexenophenone (18) & $\mathrm{IC}_{50} \mathrm{~S}$ of 2.3 and $2.5 \mu \mathrm{M}$ on MDA-MB-435 and SW-620 cell lines at $72 \mathrm{~h}$, respectively. & [12] \\
\hline (2S)-2,3-Dihydro-7-hydroxy-6,8-dimethyl-2-[(E)-prop-1-enyl]-chroman-4-one (21) & $\mathrm{IC}_{50}$ of $9.51 \mu \mathrm{g} / \mathrm{mL}$ on human breast cancer cell line MCF-7. & [4] \\
\hline (2S)-2,3-Dihydro-7-hydroxy-6-methyl-2-[(E)-prop-1-enyl]-chroman-4-one (22) & IC 50 of $7.82 \mu \mathrm{g} / \mathrm{mL}$ on human breast cancer cell line MCF-7. & [4] \\
\hline (E)-6-(2,4-Dihydroxyl-5-methylphenyl)-6-oxo-2-hexenoic acid (23) & IC $_{50}$ of $44.5 \mu \mathrm{M}$ and $72.8 \mu \mathrm{M}$ on HL-60 and P388 cell lines, respectively. & [6] \\
\hline 6-(2,4-Dihydroxyl-5-methylphenyl)-6-oxohexanoic acid (24) & $\mathrm{IC}_{50} \mathrm{~s}$ of $81.2 \mu \mathrm{M}$ and $52.5 \mu \mathrm{M}$ on HL-60 and P388 cell lines, respectively. & [6] \\
\hline 2-(2',3'-Dihydrosorbyl)-3,6-dimethyl-5-hydroxy-1,4-benzoquinone (25) & $\mathrm{IC}_{50} \mathrm{~s}$ of $15.7 \mu \mathrm{M}$ and $5.3 \mu \mathrm{M}$ on P388 and A549 cell lines, respectively. & [19] \\
\hline Bisvertinolone (34) & $\mathrm{IC}_{50}$ of $5.3 \mu \mathrm{M}$ on HL-60 cell line. & [27] \\
\hline 16,,17-Dihydrobisvertinolone (35) & $\mathrm{IC}_{50} \mathrm{~s}$ of $1.7 \mu \mathrm{M}$ and $0.52 \mu \mathrm{M}$ on P388 and A549 cell lines, respectively. & [19] \\
\hline 10,11-Dihydrobisvertinolone (36) & $\mathrm{IC}_{50}$ of $49 \mu \mathrm{M}$ on HL-60 cell line. & [27] \\
\hline Tetrahydrobisvertinolone (37) & $\mathrm{IC}_{50} \mathrm{~s}$ of $16.7 \mu \mathrm{M}$ on $\mathrm{A} 549$ cell line. & [19] \\
\hline Trichodimerol = MS-182123 (42) & $\begin{array}{l}\mathrm{IC}_{50} \text { of } 7.8 \mu \mathrm{M} \text { on HL- } 60 \text { cell line. } \\
\mathrm{IC}_{50} \text { of } 0.33 \text { and } 4.7 \mu \mathrm{M} \text { on P388 and A549 cell lines, respectively. } \\
\mathrm{IC}_{50} \mathrm{~s} \text { of } 6.55 \text { to } 28.55 \mu \mathrm{M} \text { on HL-60, U937 and T47D cell lines. }\end{array}$ & $\begin{array}{l}{[27]} \\
{[47]} \\
{[30]}\end{array}$ \\
\hline Dihydrotrichodimerol (44) & $\begin{array}{c}\mathrm{IC}_{50} \text { of } 36.4 \mu \mathrm{M} \text { on HL-60 cell line. } \\
\mathrm{IC}_{50} \mathrm{~s} \text { of } 2.8 \text { and } 2.1 \mu \mathrm{M} \text { on P388 and A549 cell lines, respectively. } \\
\mathrm{IC}_{50} \mathrm{~s} \text { of 3-34 } \mu \mathrm{M} \text { on U373, A549, SKMEL-28, OE21, Hs683, and B16F10 cell lines. }\end{array}$ & $\begin{array}{l}{[27]} \\
{[47]} \\
{[51]}\end{array}$ \\
\hline Tetrahydrotrichodimerol (45) & IC 50 of 8.8 and $4.3 \mu \mathrm{M}$ on P388 and A549 cell lines, respectively. & [47] \\
\hline Bislongiquinolide $=$ Bisorbibutenolide $=$ Trichotetronine $(\mathbf{4 9})$ & $\mathrm{IC}_{50} \mathrm{~s}$ of 4-22 $\mu \mathrm{M}$ on U373, A549, SKMEL-28, OE21, Hs683, and B16F10 cell lines. & [51] \\
\hline
\end{tabular}


Table 5. Cont.

\begin{tabular}{|c|c|c|}
\hline Sorbicillinoid & Cytotoxic Activity & Ref. \\
\hline Oxosorbiquinol (53) & $\mathrm{IC}_{50} \mathrm{~s}$ of $8.9,29.9,103.5,12.7$ and $56.3 \mu \mathrm{M}$ on HL-60, P388, A549, BEL7402 and K562 cell lines, respectively. & [2] \\
\hline Dihydrooxosorbiquinol (54) & $\mathrm{IC}_{50} \mathrm{~s}$ of $10.5,40.3,97.6,31.8$ and $68.2 \mu \mathrm{M}$ on HL-60, P388, A549, BEL7402 and K562 cell lines, respectively. & [2] \\
\hline Dihydrotrichodermolide (56) & $\mathrm{IC}_{50} \mathrm{~S}$ of 11.5 and $22.9 \mu \mathrm{M}$ on $\mathrm{P} 388$ and K562 cell lines, respevtively. & {$[36]$} \\
\hline Trisorbicillinone A (61) & IC $\mathrm{C}_{50}$ of $3.14,9.10,60.28$ and $30.21 \mu \mathrm{M}$ on HL-60, P388, BEL7402 and K562 cell lines, respectively. & [55] \\
\hline Trisorbicillinone B (62) & $\mathrm{IC}_{50} \mathrm{~s}$ of 77.1 and $88.2 \mu \mathrm{M}$ on P388 and K562 cell lines, respectively. & [56] \\
\hline Trisorbicillinone C (63) & $\mathrm{IC}_{50} \mathrm{~s}$ of 78.3 and $54.3 \mu \mathrm{M}$ on P388 and K562 cell lines, respectively. & [56] \\
\hline Trisorbicillinone D (64) & $\mathrm{IC}_{50} \mathrm{~s}$ of 65.7 and $51.2 \mu \mathrm{M}$ on P388 and K562 cell lines, respectively. & [56] \\
\hline Chloctansprirone A (74) & $\mathrm{IC}_{50} \mathrm{~s}$ of 9.2 and $39.7 \mu \mathrm{M}$ on HL-60 and A549 cell lines, respectively & [58] \\
\hline Chloctansprirone B (75) & $\mathrm{IC}_{50}$ of $37.8 \mu \mathrm{M}$ on $\mathrm{HL}-60$ cell line. & [58] \\
\hline Sorbicillactone A (85) & $\mathrm{IC}_{50}$ of $2.2 \mu \mathrm{g} / \mathrm{mL}$ on L5178y (murine leukemic lymphoblasts) cell line. & [21] \\
\hline
\end{tabular}


5'-Formyl-2'-hydroxyl-4'-methoxy-(E,E)-sorbophenone (10) showed cytotoxic activity on OSU-CLL (lymphocytic leukemia) cell lines with $\mathrm{IC}_{50}$ value of $3.1 \mu \mathrm{M}$ at $48 \mathrm{~h}$, on MDA-MB-435 (melanoma) and SW-620 (colon) cell lines with $\mathrm{IC}_{50}$ values of 1.5 and $0.5 \mu \mathrm{M}$ at $72 \mathrm{~h}$, respectively. Similarly, 1-(2'-hydroxy-4'-methoxy-5'-methylphenyl)-E,E-2,4-hexadien-1-one (9) on MDA-MB-435 and SW-620 cell lines with $\mathrm{IC}_{50}$ values of 65.2 and $15.1 \mu \mathrm{M}$, scalbucillin B (12) on MDA-MB-435 and SW-620 cell lines with $\mathrm{IC}_{50}$ values of 67.9 and $16.0 \mu \mathrm{M}$, and 5'-formyl-2'-hydroxy-4'-methoxy-(E)-4-hexenophenone (18) on MDA-MB-435 and SW-620 cell lines with $\mathrm{IC}_{50}$ values of 2.3 and $2.5 \mu \mathrm{M}$ at $72 \mathrm{~h}$, respectively [12].

(E)-6-(2,4-Dihydroxyl-5-methylphenyl)-6-oxo-2-hexenoic acid (23) and 6-(2,4-dihydroxyl-5methylphenyl)-6-oxohexanoic acid (24) from a saline lands-derived fungus Trichoderma sp. showed cytotoxic effects on P388 cell line with $\mathrm{IC}_{50}$ values of 72.8 and $44.5 \mu \mathrm{M}$, and on HL-60 cell line with $\mathrm{IC}_{50}$ values of 52.5 and $81.2 \mu \mathrm{M}$, respectively [6].

Dihydrotrichodermolide (56) and dihydrodemethylsorbicillin (17) displayed cytotoxic effects against P388 cell line ( $\mathrm{IC}_{50}$ values of 11.5 and $0.1 \mu \mathrm{M}$, respectively) and $\mathrm{K} 562$ cell line ( $\mathrm{IC}_{50}$ values of of 22.9 and $4.8 \mu \mathrm{M}$, respectively) [36].

Chloctansprirone A (74) was active against HL-60 and A549 cell lines with $\mathrm{IC}_{50}$ values of 9.2 and $39.7 \mu \mathrm{M}$, respectively. Chloctansprirone B (75) showed relatively weak activity against HL-60 cells with $\mathrm{IC}_{50}$ value of $37.8 \mu \mathrm{M}$ [58].

By comparing the structure-activity relationships of the compounds, the sorbyl sidechain was very important. Sorbicillinoids with their $\mathrm{C}_{2}{ }^{\prime}-\mathrm{C}_{3}{ }^{\prime}$ double bond being reduced were less active. For example, sorbicllin (5) showed significant inhibitory activity on HeLa and HepG2 cells with $\mathrm{IC}_{50}$ values of 1.6 and $27.2 \mu \mathrm{M}$, respectively. On the contrary, $2^{\prime}, 3^{\prime}$-dihydrosorbicillin (13) with the $\mathrm{C}_{2}{ }^{\prime}-\mathrm{C}_{3}{ }^{\prime}$ double bond being reduced showed less activity on HeLa and HepG2 cells with $\mathrm{IC}_{50}$ values of 7.4 and $44.4 \mu \mathrm{M}$, respectively. The same phenomena were observed for the compounds 6-demethylsorbicillin (7) vs. sohirnone A (14) [27], bisvertinolone (34) vs. 10,11-dihydrobisvertinolone (36) [27], and 5'-formyl-2'-hydroxyl-4'-methoxy-(E,E)-sorbophenone (10) vs. 5'-formyl-2'-hydroxy-4'-methoxy-(E)-4-hexenophenone (18) [12].

\subsection{Antimicrobial Activity}

Some sorbicillinoids exhibited antimicrobial activities that are shown in Table 6 . $5^{\prime}$-Formyl-2'-hydroxyl-4' -methoxy-(E,E)-sorbophenone (10) and 5'-formyl-2'-hydroxy-4'-methoxy-(E)4-hexenophenone (18) displayed strong antifungal activity on A. niger with MIC values of 0.05 and $0.04 \mu \mathrm{g} / \mathrm{mL}(0.20$ and $0.16 \mu \mathrm{M})$, respectively, much more potent than the positive control (amphotericin B, MIC value of $31 \mu \mathrm{g} / \mathrm{mL}$ ). Scalbucillin B (12) showed an MIC value of $0.60 \mu \mathrm{g} / \mathrm{mL}$ $(2.42 \mu \mathrm{M})$ against Aspergillus niger. Considering the potent antimicrobial activity, a hemolytic assay toward sheep red blood cells in vitro was carried out to assess the toxicity of these compounds $(\mathbf{1 0 , 1 2}$, 18). They showed a similarly low toxicity on sheep red blood cells, which indicated the promising safety for their potential application as the anti-Aspergillus agents [12].

Dihydrotrichodimerol (44) and tetrahydrotrichodimerol (45) exhibited strong antibacterial activity on Bacillus megaterium with MIC values of 25 and $12.5 \mu \mathrm{g} / \mathrm{mL}$, respectively. Dihydrotrichodimer ether A (59) and dihydrotrichodimer ether B (60) had strong antibacterial activity on Escherichia coli with MIC values of 25 and $50 \mu \mathrm{g} / \mathrm{mL}$, respectively. Furthermore, dihydrotrichodimer ether B (60) showed preferable antibacterial activity against Ballus subtilis with MIC value of $50 \mu \mathrm{g} / \mathrm{mL}$ [13].

\subsection{Antiviral Activity}

Sorbicatechols A (76) and B (77) from the marine-derived fungus Penicillium chrysogenum PJX-17 showed potent antiviral activity against influenza A virus (H1N1) with $\mathrm{IC}_{50}$ values of 85 and $113 \mu \mathrm{M}$, respectively (ribavirin as the positive control with $\mathrm{IC}_{50}$ value of $84 \mu \mathrm{M}$ ) [59]. 
Table 6. Antimicrobial activity of the screened sorbicillinoids from fungi.

\begin{tabular}{|c|c|c|}
\hline Sorbicillinoid & Antimicrobial activity & Ref. \\
\hline Oxosorbicillinol (3) & Weak antibacterial activity on Staphylococcus aureus and Bacillus subtilis. & [5] \\
\hline Sohirnone B (8) & Weak antibacterial activity on Staphylococcus aureus and Bacillus subtilis. & [5] \\
\hline $5^{\prime}$-Formyl-2'-hydroxyl-4'-methoxy-(E,E)-sorbophenone (10) & $\begin{array}{l}\text { Showed potent activity against Aspergillus flavus (NRRL 6541) and moderate activity against Fusarium verticillioides } \\
\text { (NRRL 25457). }\end{array}$ & [33] \\
\hline Scalbucillin B (12) & MIC value of $0.60 \mu \mathrm{g} / \mathrm{mL}(2.42 \mu \mathrm{M})$ against Aspergillus niger. & [12] \\
\hline $2^{\prime}, 3^{\prime}$-Dihydrosorbicillinol (13) & Weak antibacterial activity on Staphylococcus aureus and Bacillus subtilis. & [5] \\
\hline Sohirnone A (14) & Weak antibacterial activity on Staphylococcus aureus and Bacillus subtilis. & [5] \\
\hline 1-(2'-Hydroxy-4'-methoxy-5'-hydroxymethylphenyl)-E-4-hexen-1-one (16) & $\begin{array}{l}\text { Showed potent activity against Aspergillus flavus (NRRL 6541) and weak activity against Fusarium verticillioides } \\
\text { (NRRL 25457). }\end{array}$ & [33] \\
\hline 5'-Formyl-2'-hydroxy-4'-methoxy-(E)-4-hexenophenone (18) & Strong antifungal activity on Aspergillus niger with MIC values of $0.04 \mu \mathrm{g} / \mathrm{mL}(0.16 \mu \mathrm{M})$. & [12] \\
\hline $\begin{array}{c}\text { Sorrentanone } \\
\text { [=3-hydroxy-2,5-dimethyl-6-( }\left(^{\prime} \text {-oxo-2' }{ }^{\prime} \text {, }^{\prime} \text {-dienylhexyl)-1,4-benzoquione, 26] }\right.\end{array}$ & $\begin{array}{l}\text { MIC values of 32, 16, 128, 32, } 32 \text { and } 64 \mu \mathrm{\mu g} / \mathrm{mL} \text { on Staphylococcus pneumoniae A9585, S. pyogenes A9604, Enterococcus } \\
\text { faecalis A20688, S. aureus/Hetero MR A27218, S. epidermidis A24548, and S. haemolytic A21638, respectively. }\end{array}$ & [18] \\
\hline Dihydrotrichodimerol (44) & Strong antibacterial activity on Bacillus megaterium with MIC value of $25 \mu \mathrm{g} / \mathrm{mL}$. & [13] \\
\hline Tetrahydrotrichodimerol (45) & Strong antibacterial activity on Bacillus megaterium with MIC value of $12.5 \mu \mathrm{g} / \mathrm{mL}$. & [13] \\
\hline Bisvertinoquinol (47) & Weak antibacterial activity on Staphylococcus aureus and Bacillus subtilis. & [5] \\
\hline Bisorbicillinol (48) & Weak antibacterial activity on Staphylococcus aureus and Bacillus subtilis. & [5] \\
\hline Dihydrotrichodimer ether A (59) & Strong antibacterial activity on Escherichia coli with MIC value of $25 \mu \mathrm{g} / \mathrm{mL}$. & [13] \\
\hline Rezishanones A (66) & Weak antibacterial activity on Staphylococcus aureus and Bacillus subtilis. & [5] \\
\hline Rezishanone B (67) & Weak antibacterial activity on Staphylococcus aureus and Bacillus subtilis. & [5] \\
\hline Rezishanone C = Sorbivinetone (68) & Weak antibacterial activity on Staphylococcus aureus and Bacillus subtilis. & [5] \\
\hline Rezishanone D (69) & $\begin{array}{l}\text { Weak antibacterial activity on Staphylococcus aureus and Bacillus subtilis. } \\
\text { Strong antifungal activity on Aspergillus niger with MIC value of } 0.05 \mu \mathrm{g} / \mathrm{mL}(0.20 \mu \mathrm{M})\end{array}$ & $\begin{array}{c}{[5]} \\
{[12]}\end{array}$ \\
\hline
\end{tabular}


Sorbicillactone A (85) from a sponge-derived fungus Penicillium chrysogenum displayed anti-HIV activity. It protected human T lymphocytes (H9 cells) against the cytopathic effect of HIV-1 in the concentration range of 0.3 and $3.0 \mu \mathrm{g} / \mathrm{mL}$ [21]. This hybrid sorbicillinoid was considered to be a potential inhibitor to VP40 matrix protein of the Ebola virus [63].

\subsection{Antioxidant Activity}

Active oxygen species cause many diseases such as atherosclerosis, inflammation, ischemia-reperfusion injury, rheumatioid arthritis and central nervous diseases. Furthermore, senility, cancer initiation and progression are also believed to involve active oxygen species [64,65]. Thus, it is expected that the effective antioxidant agents may prevent the onset and development of these diseases. Some sorbicillinoids exhibited obviously antioxidant activity. The DPPH radical scavenging activity of the sorbicillinoids isolated before 2011 was well summarized [1]. After 2011, only one sorbicillinoid JBIR-124 (81) from Penicillium citrinum Sp1080624G1f01 was screened to have DPPH radical scavenging activity with $\mathrm{IC}_{50}$ value of $30 \mu \mathrm{M}$ [62].

\subsection{Other Biological Activities}

Other biological activities of the sorbicillinoids are shown in Table 7. Dihydrotrichodimerol (44) and bislongiquinolide (=bisorbibutenolide=trichotetronine, 49) from Trichoderma citrinoviridev influenced aphid feeding preferences [48]. Isobisvertinol (38) from Aspergillus sp. FKI-1746 inhibited lipid droplet accumulation in macrophages [40].

In addition, dihydrotrichodimerol (44) from an unidentified fungus activated peroxisome proliferator-activated receptor $\gamma(\operatorname{PPAR} \gamma)$ with an $\mathrm{ED}_{50}$ value of $80 \mathrm{ng} / \mathrm{mL}$ [50]. Bisvertinolone (34) from Verticillium intertextum inhibited the biosynthesis of $\beta-1,6-$ glucan [42].

Trichodimerol (=MS-182123, 42) from Penicillium chrysogenum strain V39673 inhibited the production of tumor necrosis factor- $\alpha$ (TNF- $\alpha$ ) by macrophages $\left(\mathrm{IC}_{50}\right.$ value of $200 \mathrm{ng} / \mathrm{mL}$ ) and monocytes ( $\mathrm{IC}_{50}$ value of $200 \mathrm{ng} / \mathrm{mL}$ ) [46]. Subsequently, trichodimerol was screened to show an inhibitory effect on lipopolysaccharide-induced eicosanoid secretion in THP-1 human monocytic cells [66].

Table 7. Other biological activities of the screened sorbicillinoids from fungi.

\begin{tabular}{|c|c|c|}
\hline Sorbicillinoid & Biological Activity & Ref. \\
\hline $6^{\prime}$-Hydroxyoxosorbicillinol (4) & $\begin{array}{l}\text { Inhibitory activity on soybean lipoxygenase; Prostaglandin D2 and leucotriene } \\
\text { B4 release suppression activity. }\end{array}$ & [22] \\
\hline Bisvertinolone (34) & Inhibitory effect on $\beta$-1,6-glucan biosynthesis & [42] \\
\hline Isobisvertinol (38) & Inhibitory effect on lipid droplet accumulation in mouse macrophages & [40] \\
\hline \multirow[t]{3}{*}{ Trichodimerol (42) } & $\begin{array}{l}\text { Inhibitory effect on bacterial endotoxin-induced production of tumor necrosis } \\
\text { factor (TNF- } \alpha \text { ) in murine macrophages and human peripheral blood } \\
\text { monocytes }\end{array}$ & [46] \\
\hline & $\begin{array}{l}\text { Inhibitory effect on lipopolysaccharide-induced eicosanoid secretion in THP-1 } \\
\text { human monocytic cells }\end{array}$ & {$[66]$} \\
\hline & $\begin{array}{l}\text { Suppression of the production of tumor necrosis factor- } \alpha \text { and nitric oxide in } \\
\text { LPS-stimulate RAW } 264.7 \text { cells }\end{array}$ & {$[50]$} \\
\hline \multirow{3}{*}{ Dihydrotrichodimerol (44) } & $\begin{array}{l}\text { Activation of peroxisome proliferator-activated recptor } \gamma(\operatorname{PPAR} \gamma) \text { with an } \\
\mathrm{ED}_{50} \text { of } 80 \mathrm{ng} / \mathrm{mL}\end{array}$ & [50] \\
\hline & $\begin{array}{l}\text { Suppression of the production of tumor necrosis factor- } \alpha \text { and nitric oxide in } \\
\text { LPS-stimulate RAW } 264.7 \text { cells }\end{array}$ & {$[50]$} \\
\hline & Effect on feeding perference of the aphid & [48] \\
\hline Bislongiquinolide (49) & Effect on feeding perference of the aphid & [48] \\
\hline Sorbiterrin A (79) & Inhibitory effect on acetylcholinesterase activity with $\mathrm{IC}_{50}$ value of $25 \mu \mathrm{g} / \mathrm{mL}$ & {$[61]$} \\
\hline
\end{tabular}

$6^{\prime}$-Hydroxyoxosorbicillinol (4) showed inhibition on soybean lipoxygenase activity with an $\mathrm{IC}_{50}$ value of $16 \mu \mathrm{M}$, about 10 folds higher than oxosorbicillinol (3). $6^{\prime}$-Hydroxyoxosorbicillinol (4) also exhibited prostaglandin $\mathrm{D}_{2}$ and leukotriene $\mathrm{B}_{4}$ release suppression activity with $\mathrm{IC}_{50}$ values of 10 and $100 \mu \mathrm{M}$, respectively [22]. 
Sorbiterrin A (79) showed moderate acetylcholinesterase (AChE) inhibitory effect with $\mathrm{IC}_{50}$ value of $25 \mu \mathrm{g} / \mathrm{mL}$ [61].

\section{Conclusions}

About 90 sorbicillinoids have been isolated from terrestrial and marine ascomycetous fungi in the past few decades. Some of them exhibited promising bioactivities, especially cytotoxic, antioxidant, antimicrobial, and antiviral activities. In recent years, more and more new members of sorbicillinoids have been isolated. All these sorbicillinoids could be the rich resources of biologically active substances with significant medicinal and agricultural potential.

The biosynthesis studies of sorbicillinoids have been carried out [11,14-17] and well summarized [1]. Sorbicillinol (1) has been hypothesized as a precursor of most sorbicillinoids that were biosynthesized by polyketide synthases (PKs) [14]. In addition, the PKS gene cluster containing SorbA, SorbB and SorbC has been characterized for sorbicillin (5) biosynthesis, and sorbicillinol (1) was proved as a key intermediate [11]. The extensive ${ }^{13} \mathrm{C}$ enrichment studies carried out by Abe and co-workers have unequivocally demonstrated that many of biosynthetic hypotheses of sorbicillinoids are correct [14-17]. There are still some uncertainties. Furthermore, the specific polyketide synthases in the biosynthetic pathway of sorbicillinoids in fungi have not been characterized. Chemical syntheses of sorbicillinoids have attracted pharmaceutical chemists as they have potential applications in the agriculture, pharmaceutical and food industries. Some sorbicillinoids such as sorbicillin (5), vertinolide (28), epoxysorbicillinol (2), and trichodimerol (=MS-182123, 42) have been synthesized successfully, and well summarized [1].

In most cases, biological activities, structure-activity relations, and mode of action of sorbicillinoids have been investigated based on in vitro studies or animal models. Few studies have been performed at the level of clinical trials in patients. Future studies should be emphasized on the improvement in methodological quality and warrant further clinical research on the effects of these compounds. The applications of sorbicillinoids as antitumor agents, antimicrobials, antivirus agents and antioxidants, as well as their underlying bioactivities, have led to considerable interest within the pharmaceutical community and health-care industry. With a good understanding of the biosynthetic pathways of some sorbicillinoids, we can not only increase outputs of the bioactive sorbicillinoids but also block biosynthesis of some harmful sorbicillinoids by specific interferences.

Acknowledgments: This work was co-financed by the grants from the National Natural Science Foundation of China (31271996 and 31471729), and the Hi-Tech R\&D Program of China (2011AA10A202).

Author Contributions: Jiajia Meng performed bibliographic research, drafted and corrected the manuscript. Xiaoxiang Fu, Xiaohan Wang, Dan Xu and Xuping Zhang retrieved literature, participated in the discussions and supported manuscript corrections. Daowan Lai reviewed the manuscript and helped to revise it. Ligang Zhou and Guozhen Zhang conceived the idea, designed the review structure, supervised manuscript drafting, and revised the manuscript. All authors read and approved the final manuscript.

Conflicts of Interest: The authors declare no conflict of interest.

\section{References}

1. Harned, A.M.; Volp, K.A. The sorbicillinoid family of natural products: Isolation, biosynthesis and synthetic studies. Nat. Prod. Rep. 2011, 28, 1790-1810. [CrossRef] [PubMed]

2. Li, D.; Wang, F.; Cai, S.; Zeng, X.; Xiao, X.; Gu, Q.; Zhu, W. Two new bisorbicillinoids isolated from a deep-sea fungus, Phialocephala sp. FL30r. J. Antibiot. 2007, 60, 317-320. [CrossRef] [PubMed]

3. Abdel-Lateff, A.; Fisch, K.; Wright, A.D. Trichopyrone and other constituents from the marine sponge-derived fungus Trichoderma sp. Z. Naturforsch. 2009, 64c, 186-192. [CrossRef]

4. $\quad$ Lan, W.-J.; Zhao, Y.; Xie, Z.-L.; Liang, L.-Z.; Shao, W.-Y.; Zhu, L.-P.; Yang, D.-P.; Zhu, X.-F.; Li, H.-J. Novel sorbicillin analogues from the marine fungus Trichoderma sp. associated with the seastar Acanthaster planci. Nat. Prod. Commun. 2012, 7, 1337-1340. [PubMed] 
5. Maskey, R.P.; Grün-Wollny, I.; Grün-Wollny, H. Sorbicillin analogues and related dimeric compounds from Penicillium notatum. J. Nat. Prod. 2005, 68, 865-870. [CrossRef] [PubMed]

6. Ma, L.; Liu, W.; Huang, Y.; Rong, X. Two acid sorbicillin analogues from saline lands-derived fungus Trichoderma sp. J. Antibiot. 2011, 64, 645-647. [CrossRef] [PubMed]

7. Ying, Y.-M.; Zhan, Z.-J.; Ding, Z.-S.; Shan, W.-G. Bioactive metabolites from Penicillium sp. P-1, a fungal endophyte in Huperzia serrata. Chem. Nat. Compd. 2011, 47, 541-544. [CrossRef]

8. Cram, D.J.; Tishler, M. Mold metabolites. I. Isolation of several compounds from clinical penicillin. J. Am. Chem. Soc. 1948, 70, 4238-4239. [CrossRef] [PubMed]

9. Cram, D.J. Mold metabolites. II. The structure of sorbicillin, a pigment produced by the mold Penicillium notatum. J. Am. Chem. Soc. 1948, 70, 4240-4243. [CrossRef] [PubMed]

10. Guo, W.; Peng, J.; Zhu, T.; Gu, Q.; Keyzers, R.A.; Li, D. Sorbicillamines A-E, nitrogen-containing sorbicillinoids from the deep-sea-derived fungus Penicillium sp. F23-2. J. Nat. Prod. 2013, 76, 2106-2112. [CrossRef] [PubMed]

11. Fahad, A.; Abood, A.; Fisch, K.M.; Osipow, A.; Davison, J.; Avramovic, M.; Butts, C.P.; Piel, J.; Simpson, T.J.; Cox, R.J. Oxidative dearomatisation: The key step of sorbicillinoid biosynthesis. Chem. Sci. 2014, 5, 523-527. [CrossRef] [PubMed]

12. El-Elimat, T.; Raja, H.A.; Figueroa, M.; Swanson, S.M.; Falkinham, J.O., III; Lucas, D.M.; Grever, M.R.; Wani, M.C.; Pearce, C.J.; Oberlies, N.H. Sorbicillinoid analogs with cytotoxic and selective anti-Aspergillus activities from Scytalidium album. J. Antibiot. 2015, 68, 191-196. [CrossRef] [PubMed]

13. Zhai, M.-M.; Qi, F.-M.; Li, J.; Jiang, C.-X.; Hou, Y.; Shi, Y.-P.; Di, D.-L.; Zhang, J.-W.; Wu, Q.-X. Isolation of secondary metabolites from the soil-derived fungus Clonostachys rosea YRS-06, a biological control agent, and evaluation of antibacterial activity. J. Agric. Food Chem. 2016, 64, 2298-2306. [CrossRef] [PubMed]

14. Abe, N.; Sugimoto, O.; Tanji, K.; Hirota, A. Identification of the quinol metabolite "Sorbicillinol", a key intermediate postulated in bisorbicillinoid biosynthesis. J. Am. Chem. Soc. 2000, 122, 12606-12607. [CrossRef]

15. Abe, N.; Yamamoto, K.; Arakawa, T.; Hirota, A. The biosynthesis of bisorbicillinoids: Evidence for a biosynthetic route from bisorbibutenolide and bisorbicillinolide. Chem. Commun. 2001, 2001, $23-24$. [CrossRef]

16. Abe, N.; Arakawa, T.; Yamamoto, K.; Hirota, A. Biosynthesis of bisorbicillinoid in Trichoderma sp. USF-2690; evidence for the biosynthetic pathway, via sorbicillinol, of sorbicillin, bisorbicillinol, bisorbibutenolide, and bisorbicillinolide. Bisosci. Biotechnol. Biochem. 2002, 66, 2090-2099. [CrossRef]

17. Sugaya, K.; Koshino, H.; Hongo, Y.; Yasunaga, K.; Onose, J.; Yoshikawa, K.; Abe, N. The biosynthesis of sorbicillinoids in Trichoderma sp. USF-2690: Prospect for the existence of a common precursor to sorbicillinol and 5-epihydroxyvertinolide, a new sorbicillinoid member. Tetrahedron Lett. 2008, 49, 654-657. [CrossRef]

18. Miller, R.F.; Huang, S. Isolation and structure of sorrentanone: A new tetrasubstituted quinone from Penicillium chrysogenum. J. Antibiot. 1995, 48, 520-521. [CrossRef] [PubMed]

19. Liu, W.; Gu, Q.; Zhu, W.; Cui, C.; Fan, G. Two new benzoquinone derivatives and two new bisorbicillinoids were isolated from a marine-derived fungus Penicillium terrestre. J. Antibiot. 2005, 58, 441-446. [CrossRef] [PubMed]

20. Sperry, S.; Samuels, G.J.; Crews, P. Vertinoid polyketides from the saltwater culture of the fungus Trichoderma longibrachiatum separated from a Haliclona marine sponge. J. Org. Chem. 1998, 63, 10011-10014. [CrossRef]

21. Bringmann, G.; Lang, G.; Gulder, T.A.M.; Tsuruta, H.; Mühlbacher, J.; Maksimenka, K.; Steffens, S.; Schaumann, K.; Stohr, R.; Wiese, J.; et al. The first sorbicillinoid alkaloids, the antileukemic sorbicillactones A and B, from a sponge-derived Penicillium chrysogenum strain. Tetrahedron 2005, 61, 7252-7265. [CrossRef]

22. Komoda, T.; Nishikawa, M. 6'-Hydroxyoxosorbicillinol, a new lipoxygenase inhibitor and $\mathrm{PGD}_{2} / \mathrm{LTB}_{4}$ release suppressor from Penicillium sp. Biosci. Biotechnol. Biochem. 2012, 76, 1404-1406. [CrossRef] [PubMed]

23. Abe, N.; Yamamoto, K.; Hirota, A. Novel fungal metabolites, demethylsorbicillin and oxosorbicillinol, isolated from Trichoderma sp. USF-2690. Biosci. Biotechnol. Biochem. 2000, 64, 620-622. [CrossRef] [PubMed]

24. Saito, T.; Itabashi, T.; Wakana, D.; Takeda, H.; Yaguchi, T.; Kawai, K.; Hosoe, T. Isolation and structure elucidation of new phthalide and phthalane derivatives, isolated as antimicrobial agents form Emericella sp. IFM57991. J. Antibiot. 2016, 69, 89-96. [CrossRef] [PubMed]

25. Arima, K.; Nakamura, H.; Komagata, K. Studies on variation of penicillin producing mold. Part II. Biochemical genetical studies on the yellow pigments losing mutation of chrysogenum Q 176 to pigmentless sultant Pen. chrysogenum Q 176. J. Agric. Chem. Soc. Jpn. 1953, 27, 345-348. 
26. Andrade, R.; Ayer, W.A.; Mebe, P.P. The metabolites of Trichoderma longibrachiatum. Part 1. Isolation of the metabolites and the structure of trichodimerol. Can. J. Chem. 1992, 70, 2526-2535. [CrossRef]

27. Du, L.; Zhu, T.; Li, L.Y.; Cai, S.; Zhao, B.; Gu, Q. Cytotoxic sorbicillinoids and bisorbicillinoids from a marine-derived fungus Trichoderma sp. Chem. Pharm. Bull. 2009, 57, 220-223. [CrossRef] [PubMed]

28. Wu, S.H.; Zhao, L.X.; Chen, Y.W.; Huang, R.; Miao, C.P.; Wang, J. Sesquiterpenoids from the endophytic fungus Trichoderma sp. PR-35 of Paeonia delavayi. Chem. Biodivers. 2011, 8, 1717-1723.

29. Abe, N.; Murata, T.; Hirota, A. Novel oxidized sorbicillin dimers with 1,1-diphenyl-2-picrylhydrazyl-radial scavenging activity from a fungus. Biosci. Biotechnol. Biochem. 1998, 62, 2120-2126. [CrossRef]

30. Yao, Y.; Li, J.; Jiang, C.-S.; Zhao, X.-X.; Miao, Z.-H.; Liu, H.-T.; Zheng, P.; Yao, W.-X.; Li, W.-Q. Trichodimerol and sorbicillin induced apoptosis of HL-60 cells is mediated by reactive oxygen species. Pharmazie 2015, 70, 394-398. [PubMed]

31. Trifonov, L.S.; Dreiding, A.S.; Hoesch, L.; Rast, D.M. Isolation of four hexaketides from Verticillium intertextum. Helv. Chim. Acta 1981, 64, 1843-1846. [CrossRef]

32. Trifonov, L.S.; Bieri, J.H.; Prewo, R.; Dreiding, A.S. Isolation and structure elucidation of three metabolites from Verticillium intertextum: Sorbicillin, dihydrosorbicillin and bisvertinoquinol. Tetrahedron 1983, 39, 4243-4256. [CrossRef]

33. Reátegui, R.F.; Wicklow, D.T.; Gloer, J.B. Phaeofurans and sorbicillin analogues from a fungicolous Phaeoacremonium species (NRRL 32148). J. Nat. Prod. 2006, 69, 113-117. [CrossRef] [PubMed]

34. Geigert, J.; Stermitz, F.R.; Schroeder, H.A. Two new natural substituted hexenophenones from the fungus Scytalidium. Tetrahedron 1973, 29, 2343-2345. [CrossRef]

35. Bringmann, G.; Lang, G.; Bruhn, T.; Schäffler, K.; Steffens, S.; Schmaljohann, R.; Wiese, J.; Imhoff, J.F. Sorbifuranones A-C, sorbicillinoid metabolites from Penicillium strains isolated from Mediterranean sponges. Tetrahedron 2010, 66, 9894-9901. [CrossRef]

36. Li, D.; Cai, S.; Zhu, T.; Wang, F.; Xiao, X.; Gu, Q. New cytotoxic metabolites from a deep-sea-derived fungus, Phialocephala sp., strain FL30r. Chem. Biodivers. 2011, 8, 895-901. [CrossRef] [PubMed]

37. Neumann, K.; Abdel-Lateff, A.; Wright, A.D.; Kehraus, S.; Krick, A.; König, G.M. Novel sorbicillin derivatives with an unprecedented carbon skeleton from the sponge-derived fungus Trichoderma species. Eur. J. Org. Chem. 2007, 2007, 2268-2275. [CrossRef]

38. Trifonov, L.S.; Bieri, J.H.; Prewo, R.; Dreiding, A.S.; Rast, D.M.; Hoesch, L. The constitution of vertinolide, a new derivative of tetronic acid, produced by Verticillium intertextum. Tetrahedron 1982, 38, 397-403. [CrossRef]

39. Andrade, R.; Ayer, W.A.; Trifonov, L.S. The metabolites of Trichoderma longibrachiatum III. Two new tetronic acids: 5-hydroxyvertinolide and bislongiquinolide. Aust. J. Chem. 1997, 50, 255-257. [CrossRef]

40. Koyama, N.; Ohshiro, T.; Tomoda, H.; Ōmura, S. Fungal isobisvertinol, a new inhibitor of lipid droplet accumulation in mouse macrophages. Org. Lett. 2007, 9, 425-428. [CrossRef] [PubMed]

41. Trifonov, L.S.; Hilpert, H.; Floersheim, P.; Dreiding, A.S.; Rast, D.M.; Skrivanova, R.; Hoesch, L. Bisvertinols: A new group of dimeric vertinoids from Verticillium intertextum. Tetrahedron 1986, 42, 3157-3179. [CrossRef]

42. Kontani, M.; Sakagami, Y.; Marumo, S. Frist $\beta$-1,6-giucan biosynthesis inhibitor, bisvertinolone isolated from fungus, Acremonium stricturn and its absolute stereochemistry. Tetrahedron Lett. 1994, 35, 2577-2580. [CrossRef]

43. Ueda, J.; Hashimoto, J.; Inaba, S.; Takagi, M.; Shin-ya, K. JBIR-59, a new sorbicillinoid, from a marine-derived fungus Penicillium citrinum SpI080624G1f01. J. Antibiot. 2010, 63, 203-205. [CrossRef] [PubMed]

44. Abe, N.; Murata, T.; Hirota, A. Novel DPPH radical scavengers, bisorbicillinol and demethyltrichodimerol, from a fungus. Biosci. Biotechnol. Biochem. 1998, 62, 661-666. [CrossRef]

45. Gao, Q.; Leet, J.E.; Thomas, S.T.; Matson, J.A. Crystal structure of trichodimerol. J. Nat. Prod. 1995, 58, 1817-1821. [CrossRef]

46. Warr, G.A.; Veitch, J.A.; Walsh, A.W.; Hesler, G.A.; Pirnik, D.M.; Leet, J.E.; Lin, P.-F.M.; Medina, I.A.; McBrien, K.D.; Forenza, S.; et al. BMS-182123, a fungal metabolite that inhibits the production of TNF- $\alpha$ by macrophage and monocytes. J. Antibiot. 1996, 49, 234-240. [CrossRef] [PubMed]

47. Liu, W.; Gu, Q.; Zhu, W.; Cui, C.; Fan, G. Dihydrotrichodimerol and tetrahydrotrichodimerol, two new bisorbicillinoids, from a marine-derived Penicillium terrestre. J. Antibiot. 2005, 58, 621-624. [CrossRef] [PubMed] 
48. Evidente, A.; Andolfi, A.; Cimmino, A.; Ganassi, S.; Altomare, C.; Favilla, M.; Cristofaro, A.D.; Vitagliano, S.; Sabatini, M.A. Bisorbicillinoids produced by the fungus Trichoderma citrinoviride affect feeding preference of the aphid Schizaphis graminum. J. Chem. Ecol. 2009, 35, 533-541. [CrossRef] [PubMed]

49. Shirota, O.; Pathak, V.; Hossain, C.F.; Sekita, S.; Takatori, K.; Satake, M. Structural elucidation of trichotetronines: Polyketides possessing a bicycle [2.2.2] octane skeleton with a tetronic acid moiety isolated from Trichoderma sp. J. Chem. Soc. Perk. Trans. 1 1997, 1997, 2961-2964. [CrossRef]

50. Lee, D.; Lee, J.H.; Cai, X.F.; Shin, J.C.; Lee, K.; Hong, Y.-S.; Lee, J.J. Fungal metabolites, sorbicillinoid polyketides and their effects on the activation of peroxisome proliferator-activated receptor $\gamma$. J. Antibiot. 2005, 58, 615-620. [CrossRef] [PubMed]

51. Balde, E.S.; Andolfi, A.; Bruyère, C.; Cimmino, A.; Lamoral-Theys, D.; Vurro, M.; Damme, M.V.; Altomare, C.; Mathieu, V.; Kiss, R.; et al. Investigations of fungal secondary metabolites with potential anticancer activity. J. Nat. Prod. 2010, 73, 969-971. [CrossRef] [PubMed]

52. Abe, N.; Murata, T.; Yamamoto, K.; Hirota, A. Bisorbibetanone, a novel oxidized sorbicillin dimer, with 1,1-diphenyl-2-picrylhydrazyl radical scavenging activity from a fungus. Tetrahedron Lett. 1999, 40, 5203-5206. [CrossRef]

53. Washida, K.; Abe, N.; Sugiyama, Y.; Hirota, A. Novel DPPH radical scavengers, demethylbisorbibutenolide and trichopyrone, from a fungus. Biosci. Biotech. Biochem. 2007, 71, 1052-1057. [CrossRef] [PubMed]

54. Andrade, R.; Ayer, W.A.; Trifonov, L.S. The metabolites of Trichoderma longibrachiatum Part II. The structures of trichodermolide and sorbiquinol. Can. J. Chem. 1996, 74, 371-379. [CrossRef]

55. Li, D.; Wang, F.; Xiao, X.; Fang, Y.; Zhu, T.; Gu, Q.; Zhu, W. Trisorbicillinone A, a novel sorbicillin trimer, from a deep sea fungus, Phialocephala sp. FL30r. Tetrahedron Lett. 2007, 48, 5235-5238. [CrossRef]

56. Li, D.; Cai, S.; Zhu, T.; Wang, F.; Xiao, X.; Gu, Q. Three new sorbicillin trimers, trisorbicillinones B, C, and D, from a deep ocean sediment derived fungus, Phialocephala sp. FL30r. Tetrahedron 2010, 66, 5101-5106. [CrossRef]

57. Cabrera, G.M.; Butler, M.; Rodriguez, A.; Godeas, A.; Haddad, R.; Eberlin, M.N. A sorbicillinoid urea from an intertidal Paecilomyces marquandii. J. Nat. Prod. 2006, 69, 1806-1808. [CrossRef] [PubMed]

58. Li, D.; Chen, L.; Zhu, T.; Kurtán, T.; Mándi, A.; Zhao, Z.; Li, J.; Gu, Q. Chloctanspirones A and B, novel chlorinated polyketides with an unprecedented skeleton, from marine sediment derived fungus Penicillium terrestre. Tetrahedron 2011, 67, 7913-7918. [CrossRef]

59. Peng, J.; Zhang, X.; Du, L.; Wang, W.; Zhu, T.; Gu, Q.; Li, D. Sorbicatechols A and B, antiviral sorbicillinoids from the marine- derived fungus Penicillium chrysogenum PJX-17. J. Nat. Prod. 2014, 77, 424-428. [CrossRef] [PubMed]

60. Washida, K.; Abe, N.; Sugiyama, Y.; Hirta, A. Novel secondary metabolites, spirosorbicillinols A, B, and C, from a fungus. Biosci. Biotech. Biochem. 2009, 73, 1355-1361. [CrossRef] [PubMed]

61. Chen, L.; Zhu, T.; Ding, Y.; Khan, I.A.; Gu, Q.; Li, D. Sorbiterrin A, a novel sorbicillin derivative with cholinesterase inhibition activity from the marine-derived fungus Penicillium terrestre. Tetrahedron Lett. 2012, 53, 325-328. [CrossRef]

62. Kawahara, T.; Takagi, M.; Shin-ya, K. JBIR-124: A novel antioxidative agent from a marine sponge-derived fungus Penicillium citrinum SpI080624G1f01. J. Antibiot. 2012, 65, 45-47. [CrossRef] [PubMed]

63. Skariyachan, S.; Acharya, A.B.; Subramaniyan, S.; Babu, S.; Kulkarni, S.; Narayanappa, R. Secondary metabolites extracted from marine sponge associated Comamonas testosterone and Citrobacter freundii as potential antimicrobials against MDR pathogens and hypothetical leads for VP40 matrix protein of Ebola virus: An in vitro and in silico investigation. J. Biomol. Struct. Dyn. 2016, 34.

64. Finkel, T. Radical medicine: Treating ageing to cure disease. Nat. Rev. Mol. Cell Biol. 2005, 6, 971-976. [CrossRef] [PubMed]

65. Abe, N.; Hirota, A. Chemical studies of the radical scavenging mechanism of bisorbicillinol using the 1,1-diphenyl-2-picrylhydrzyl radical. Chem. Commun. 2002, 2002, 662-663. [CrossRef]

66. Mazzucco, C.E.; Warr, G. Trichodimerol (BMS-182123) inhibits lipopolysaccharide-induced eicosanoid secretion in THP-1 human monocytic cells. J. Leukocyte Biol. 1996, 60, 271-277. [PubMed]

(C) 2016 by the authors; licensee MDPI, Basel, Switzerland. This article is an open access article distributed under the terms and conditions of the Creative Commons Attribution (CC-BY) license (http://creativecommons.org/licenses/by/4.0/). 